NBER WORKING PAPER SERIES

\title{
GLOBALIZATION, GOVERNANCE, AND THE RETURNS TO CROSS-BORDER ACQUISITIONS
}

\author{
Jesse Ellis \\ Sara B. Moeller \\ Frederik P. Schlingemann \\ René M. Stulz \\ Working Paper 16676 \\ http://www.nber.org/papers/w16676
}

\author{
NATIONAL BUREAU OF ECONOMIC RESEARCH \\ 1050 Massachusetts Avenue \\ Cambridge, MA 02138 \\ January 2011
}

The authors gratefully acknowledge funding for this project from the International Business Center at the University of Pittsburgh. We thank Isil Erel for helpful comments and Rose Lau for excellent research assistance. The views expressed herein are those of the authors and do not necessarily reflect the views of the National Bureau of Economic Research.

NBER working papers are circulated for discussion and comment purposes. They have not been peerreviewed or been subject to the review by the NBER Board of Directors that accompanies official NBER publications.

(C) 2011 by Jesse Ellis, Sara B. Moeller, Frederik P. Schlingemann, and René M. Stulz. All rights reserved. Short sections of text, not to exceed two paragraphs, may be quoted without explicit permission provided that full credit, including $(\odot)$ notice, is given to the source. 
Globalization, Governance, and the Returns to Cross-Border Acquisitions

Jesse Ellis, Sara B. Moeller, Frederik P. Schlingemann, and René M. Stulz

NBER Working Paper No. 16676

January 2011

JEL No. G31,G32,G34

\begin{abstract}
Using a sample of control cross-border acquisitions from 61 countries from 1990 to 2007, we find that acquirers from countries with better governance gain more from such acquisitions and their gains are higher when targets are from countries with worse governance. Other acquirer country characteristics are not consistently related to acquisition gains. For instance, the anti-self-dealing index of the acquirer has opposite associations with acquirer returns depending on whether the acquisition of a public firm is paid for with cash or equity. Strikingly, global effects in acquisition returns are at least as important as acquirer country effects. First, the acquirer's industry and the year of the acquisition explain more of the stock-price reaction than the country of the acquirer. Second, for acquisitions of private firms or subsidiaries, acquirers gain more when acquisition returns are high for acquirers from other countries. We find strong evidence that better alignment of interests between insiders and minority shareholders is associated with greater acquirer returns and weaker evidence that this effect mitigates the adverse impact of poor country governance.
\end{abstract}

Jesse Ellis

Katz Graduate School of Business

University of Pittsburgh

219 Mervis Hall

Pittsburgh, PA 15260

jellis@katz.pitt.edu

Sara B. Moeller

Katz Graduate School of Business

University of Pittsburgh

360 Mervis Hall

Pittsburgh, PA 15260

sbmoeller@katz.pitt.edu
Frederik P. Schlingemann

Katz Graduate School of Business

University of Pittsburgh

372 Mervis Hall

Pittsburgh, PA 15260

schlinge@katz.pitt.edu

René M. Stulz

The Ohio State University

Fisher College of Business

806A Fisher Hall

2100 Neil Avenue

Columbus, $\mathrm{OH}$ 43210-1144

and NBER

stulz_1@cob.osu.edu 


\section{Introduction}

There is a vast literature showing that a country's governance is related to characteristics of its financial markets as well as of its firms. In particular, countries with better governance are countries with more developed financial markets, more initial public offerings, less unmet financing requirements, greater valuation of cash held by investors, and so on. ${ }^{1}$ We expect corporate investments in countries with better governance to increase shareholder wealth more. In particular, shareholders in countries with better governance should be better able to protect themselves against expropriation by insiders, by the state, as well as by other parties. Further, investments by corporations should face fewer obstacles in countries where the government works better, regulation is less burdensome, and corruption is weaker. However, firms can also take actions that offset the weaknesses of their country's governance. For instance, greater insider ownership can help align interests between insider and minority shareholders (Jensen and Meckling, 1976; Shleifer and Wolfenzon, 2002) and cross-listing enables firms to rent institutions from countries with better governance and investor protection (Coffee, 1999; Stulz, 1999). As a result of these opposing effects, it is an empirical issue whether and how a country's governance affects the extent to which investments create wealth for shareholders.

In this paper, we investigate whether a country's governance explains the shareholder wealth created by investment decisions by studying the stock-price reaction to cross-border control acquisitions. Acquisitions are typically the largest discrete operating investments firms make (Jensen and Ruback, 1983). Cross-border acquisitions offer an ideal setting to study this issue. The cross-border acquisitions firms make are typically acquisitions that are available to firms from many countries, so the price a firm pays for an acquisition is generally set in a global market. Cross-border acquisitions make it possible, therefore, to separate the investment decision from the investment opportunity set in a way that is not be possible for domestic acquisitions. Importantly, this separation enables us to focus more directly on the country governance of the acquiring firm. In the absence of this separation, it is difficult to separate the impact of country governance on the acquirer versus its impact on the target. In this paper, we can

\footnotetext{
${ }^{1}$ See Olsen (1996) on the importance and implications of country governance. La Porta, Lopez-de-Silanes, Shleifer, and Vishny (2002) review some of the literature from the perspective that the key determinant of country governance is a country's legal origin. The result on the value of cash is in Pinkowitz, Stulz, and Williamson (2006).
} 
identify separately the impact of acquiring-firm country governance and target-firm country governance. We find, for the whole sample of acquisitions, the gains to acquiring-firm shareholders are higher in countries with better governance and firms in such countries make more acquisitions.

We construct a sample of 37,414 control acquisitions by firms in 61 countries from 1990 to 2007. Out of these acquisitions, 8,090 are cross-border acquisitions. It is not surprising that most acquisitions are domestic. It is well-known in the acquisitions literature that the returns to acquiring-firm shareholders from acquisitions differ depending on the type of acquisition (see, for instance, Fuller, Netter, and Stegemoller, 2002). We therefore consider all types of acquisitions together as well as each type of acquisition separately. Acquisitions of private firms constitute the most frequent type of acquisitions both domestically and cross-border. The relative frequency of acquisitions paid for with stock is much lower for cross-border acquisitions than for domestic acquisitions. Strikingly, we show that, for all acquisitions except acquisitions of public firms for cash, there is no difference in the average stock-price reaction to domestic acquisitions and cross-border acquisitions. In the case of acquisitions of public firms for cash, we find that cross-border acquisitions have an abnormal return that is greater by $0.56 \%$. As in the literature for U.S. acquisitions, all types of acquisitions but those of public firms paid for with common stock generate a positive stock-price reaction.

We investigate next how country governance and other country characteristics are related to acquirer shareholder returns. We expect better country governance to lead to acquisitions that benefit shareholders for several reasons. First, better governance makes it less likely that proceeds from investments will be expropriated by the state, insiders, stakeholders, or others. Second, it makes it harder for insiders to make investments that benefit them at the expense of shareholders. Third, better country governance gives an advantage to firms in creating synergies through acquisitions. For example, poor respect for the rule of law and poor control of corruption have an adverse impact on how well a firm conducts its operations. As a result, a firm from a country with good governance that acquires a firm from a country with poor governance can make the target more efficient. We use as our main measures of country governance the World Governance Indicators published by the World Bank (see Kaufmann, Kraay, and Mastruzzi [KKM], 2009). These indices are time-varying and are obtained by averaging a large number of surveys. 
They measure separately how well a country controls corruption, the respect for the rule of law, the degree of political stability, the effectiveness of government, regulatory quality, and how well a country's citizens can participate in selecting the government and the extent to which they enjoy various freedoms. We investigate the relation between acquirer gains and each one of the individual indices as well as with the aggregate index for the acquirer's country. For the whole cross-border sample, the average acquirer abnormal return is $1.5 \%$. A one standard deviation increase in the average country governance index increases the stock-price reaction by 23 basis points, or $14.97 \%$. We find that, in general, acquirer gains increase with better control of corruption, better rule of law, and better government effectiveness in the acquirer's country. In addition, the acquirer gain for acquisitions of public firms for cash increase significantly with these three indices as well, but also increase strongly with the index of government stability. The effect of a one standard deviation increase in the average governance index on the abnormal return for acquisitions of public firms paid for with cash is an increase of $60.65 \%$. In multiple regressions, country governance of the acquirer has a positive significant coefficient for the whole sample, for cash acquisitions of public and private firms, and for stock acquisitions of private firms.

We investigate other country characteristics expected to be related to the gains shareholders make from acquisitions. We find that the stock-price reaction to acquisitions of public firms for cash increases in an economically significant way with the acquiring country's accounting transparency and its anti-selfdealing index, an index that measures the ability of insiders to engage in self-dealing transactions (see Djankov, La Porta, Lopez-de-Silanes, and Shleifer, 2003), but acquiring-firm returns for acquisitions of public firms paid for with equity fall with the anti-self-dealing index. Though the literature has devoted considerable attention to the role of the anti-director index in the frequency of acquisitions and in merger premiums since Rossi and Volpin (2004), we find no evidence that acquirers from countries with a higher anti-director index gain more from acquisitions. Characteristics related to a country's economic or financial development are typically not significant.

In all our regressions, we include a country characteristic both for the acquirer's country and for the target's country. A striking result is that the coefficient of the characteristic for the target's country has often the opposite sign of the coefficient for the acquirer's country. Most importantly given our focus, the 
coefficient on the governance index of the target's country is generally negative, so that the gain from acquisitions for acquiring-firm shareholders is generally lower if the acquisition is made in a country with better governance. This result implies that the benefits of good country governance are portable, in that a firm from a country with good governance carries the benefits of that good governance with it when it goes abroad.

The results we have discussed generally hold in many different regression specifications. In particular, we estimate regressions with only one country characteristic at a time as well as with multiple country characteristics. We would expect firm and deal characteristics to be endogenous to country characteristics. We therefore estimate regressions without firm and deal characteristics as well as regressions with these characteristics. Our main results hold in all of these specifications.

We then explore whether two firm-level governance choices, namely insider ownership and the choice of an ADR program, mitigate the effect of poor country governance. Though there is evidence that corporate control mechanisms affect acquirer returns in the U.S. (Masulis, Wang, and Xie, 2007), U.S. evidence on the relation between bidder returns and insider ownership is mixed (for instance, while Hubbard and Palia (1995) find a nonlinear relation between bidder returns and managerial ownership, Loderer and Martin (1997) find no relation). In contrast, we find strong evidence that acquirer returns increase with insider ownership in our cross-country sample. The economic significance of a one standard deviation increase in insider ownership for the whole sample is an increase of $18 \%$ in the acquirer return. There is some evidence that the benefit from insider ownership decreases as the quality of a country's governance increases, but this evidence is significant only for acquisitions of private firms. Surprisingly, the existence of an ADR program is negatively related to returns of acquisitions of public firms for stock. A possible explanation is that the information environment is better for ADR firms (see Bailey, Karolyi, and Salva, 2006), so that stock issuance has more signaling value for such firms.

As Black (2000) observes, merger waves have become global. The frequency of cross-border acquisitions shows that there is a global market for control. We would therefore expect global factors to affect the gains from acquisitions and the frequency of acquisitions. To capture global effects, we first use year and industry indicator variables. For the whole sample, we find that these indicator variables have 
more explanatory power than country characteristics, suggesting that global determinants of stock-price reactions to acquisitions are important. We show further that an acquirer's return for an acquisition is related to acquirer returns in other countries for the same type of transaction and form of payment. This effect is strong for the whole sample and for acquisitions of private firms and subsidiaries; it is not for acquisitions of public firms.

If a country's governance is a valuable input in the production function of firms, we would expect firms from countries with poor governance to find it more difficult to compete for acquisitions. As a result, governance should affect not only the gains of acquisitions but also whether acquisitions take place. We find that this is indeed the case. We show across all types of acquisitions that the frequency of acquisitions is strongly positively related to the governance of a country. In other words, if a firm is in a country with better governance, it makes more cross-border acquisitions. Other country characteristics are generally insignificant after controlling for industry and year.

We proceed as follows. In Section 2, we review the relevant literature. In Section 3, we explain how we construct our sample and how we estimate abnormal returns. We show estimates of the stock-price reaction to cross-border and domestic acquisitions in Section 4. In Section 5, we investigate the relation between acquiring-firm shareholder gains from cross-border acquisitions and characteristics of the acquiring firm's country using several different approaches. In Section 6, we show that country governance is positively related to the frequency of acquisitions. We conclude in Section 7.

\section{Review of the literature}

There is a growing literature on cross-border acquisitions. Part of this literature focuses on understanding the frequency of such acquisitions. Another part of the literature tries to explain shareholder gains. In this brief review, we discuss only the literature addressing control acquisitions by publicly traded firms, which is the topic of this paper.

Early papers on cross-border mergers and acquisitions are more concerned about issues related to the benefits of foreign direct investment (FDI) and the value created by international corporate 
diversification. An early paper by Harris and Ravenscraft (1991) approaches cross-border acquisitions from the same perspective as the FDI literature does. ${ }^{2}$ It shows that cross-border acquisitions are more frequent in R\&D intensive industries. The more recent literature on country determinants of mergers and acquisitions activity starts with Rossi and Volpin (2004). Like us, they focus on control acquisitions and include private firm targets in their sample (22\% of their acquisitions have a public company as the target). In their analysis of target countries, they find that countries with weaker shareholder protection are the targets of fewer cross-border acquisitions. They do not focus on characteristics of acquiring countries separately. In their analysis of acquirer/target country pairs, they show that acquirers typically come from countries with better accounting standards and stronger shareholder protection than the targets. In contrast to Rossi and Volpin (2004), Erel, Liao, and Weisbach (2010) also consider partial acquisitions and include in their sample acquisitions made by non-public firms (Karolyi and Liao (2010) show that state-related entities are important acquirers as well). Their study shows that firms from countries whose currency has appreciated tend to invest in countries whose currency has depreciated. Ferreira, Massa, and Matos (2009) show that cross-border acquisitions are more likely to occur in countries where foreign institutional investors hold a higher fraction of the local stock market. Finally, Ahern, Daminelli, and Fracassi (2010) examine the impact of cultural values on cross-border activity and find that the frequency of cross-border acquisitions is lower between pairs of countries that are more culturally distant.

Papers that investigate stock-price reactions to cross-border acquisitions tend to have two different perspectives. Some papers focus on acquirer returns trying to assess whether international corporate diversification benefits shareholders and do so often from the perspective of the corporate diversification literature. Other papers study instead whether the gains to acquirers or targets are related to country characteristics. Many papers focus only on cross-border acquisitions involving a U.S. firm.

Papers focusing on the benefits of international corporate diversification include Doukas and Travlos (1988), who show that firms that enter a new geographic market earn a higher abnormal return. Eun,

\footnotetext{
${ }^{2}$ The paper references many papers in the FDI literature concerned about investment flows that we do not review here.
} 
Kolodny, and Scheraga (1996) provide evidence that cross-border acquisitions of U.S. targets create positive synergies. Dos Santos, Errunza, and Miller (2008) look at changes in the diversification discount around cross-border acquisitions. They conclude that diversifying cross-border acquisitions destroy value. Moeller and Schlingemann (2005) investigate acquisitions of foreign firms by U.S. firms from 1985 to 1995. They find that acquirer returns for cross-border acquisitions are lower by about 100 basis points than for domestic acquisitions. They attribute this result to transactions that increase the acquirer's global diversification and industry diversification. Harris and Ravenscraft (1991) fail to find evidence that target premiums can be explained by industry considerations, but they show that premiums are related to exchange rate movements, so that the higher premiums they document for acquisitions by foreign firms seem to be partly explained by weakness of the dollar.

Bris and Cabolis (2008) focus on the premium in cross-border acquisitions. Their sample includes partial acquisitions. They consider only acquisitions of public companies and do not analyze the returns to acquirers. They show that 100 percent control acquisitions of target firms in weak shareholder protection countries made by acquiring firms in strong shareholder protection countries result in a higher premium than comparable domestic acquisitions in the weak shareholder protection countries. Starks and Wei (2004) conclude that takeover premia received by U.S. firms acquired by foreign firms from 1980 to 1998 are decreasing in the quality of corporate governance in the acquiring country and that acquiring-firm returns are increasing in the quality of corporate governance in their country when the acquisition is paid for with stock but not otherwise. Kuipers, Miller, and Patel (2003) examine acquisitions of U.S. companies by foreign companies. They find that the acquirer's return increases in the degree of shareholder protection in the acquirer's country, but falls in the product of the degree of shareholder protection and the respect of the rule of law, so that shareholder protection does not seem to be related to acquirer returns in countries where the respect of the rule of law is high. Martynova and Renneboog (2008) find that the three-day announcement return is lower for cross-border acquisitions than for domestic acquisitions for acquisitions from European countries. Using indices of the quality of corporate governance at the country level, they show that acquisition returns for bidders and targets in cross-border 
acquisitions are higher when the bidder comes from a country with better corporate governance than the target. Burns, Francis, and Iftekhar (2007) examine the role of ADR programs in cross-border acquisitions. They find that foreign firms with ADR programs pay less for U.S. targets, but they also show that the existence of an ADR program does not offset poor investor protection at home for a foreign firm.

Several recent papers investigate other determinants of acquisition returns besides investor protection and corporate governance. Chari, Ouimet, and Tesar (2009) find, using a sample of acquisitions from 1986 to 2006, that developed-market acquirers earn 1.16\% on average when an emerging-market firm is acquired, but do not earn a significant positive abnormal return when acquiring targets in developed countries. Their total sample of cross-border acquisitions is slightly more than a third of ours despite including acquisitions of minority stakes. They find that acquirer returns increase as respect for the rule of law in the acquirer's country increases relative to the target's country, but only for control acquisitions. Ferreira, Massa, and Matos (2010) also obtain estimates of abnormal returns for acquirers. They show a negative average acquirer return of $-0.78 \%$ for a sample of 176 acquisitions. They focus on the combined return to the acquirer and the target. They conclude that this combined return increases in the foreign institutional ownership of the bidder and the foreign institutional ownership of the target. They use acquirer insider ownership as a control variable, but do not report the coefficient. Ahearn, Daminelli, and Fracassi (2010) investigate the value created by cross-border acquisitions. However, they only pursue that investigation focusing on the combined return to the acquirer and the target and do not evaluate whether acquirers benefit from cross-border acquisitions. Because of their investigation of combined returns, they have a sample of 938 cross-border mergers across 38 countries. The size of this sample is comparable to the size of our sample of cross-border acquisitions with public targets. They conclude that the combined returns in acquisitions are lower when the countries of the acquirer and the target are more culturally distant.

In summary, the existing literature has mixed results on whether acquirers gain from cross-border acquisitions, as the estimated stock-price reaction to cross-border acquisitions is negative in some studies 
and positive in others. The literature also reaches mixed results on how country and firm characteristics are related to the stock-price reaction. For instance, some papers find evidence of an impact of countrylevel investor protection for some types of transactions but not for others. Our paper adds to that literature, among other reasons, by demonstrating that the return from cross-border acquisitions is affected in an economically important way by country governance, globalization, and corporate governance.

\section{Data}

We discuss first how we construct the sample of acquisitions and then how we estimate abnormal returns. In the final part of the section, we describe the firm and country variables we use.

\subsection{The sample of acquisitions.}

To obtain our sample of acquisitions, we use the Securities Data Company’s (SDC) Global Mergers and Acquisition database for the merger and acquisition sample. We begin with collecting data on all acquirers and targets in completed deals for control from 1990-2007. We consider only deals for control where the acquirer owns less than $50 \%$ of the target before the acquisition and more than $50 \%$ afterwards. We only include deals where the target is public, private, or a subsidiary, and therefore exclude spin-offs, recaps, buybacks, self-tenders, or exchange offers. We delete deals where SDC classifies the target as private, yet the stock price information is available. A difficulty with subsidiary targets is that the subsidiary could be located in a foreign country but the parent could be located in the same country as the acquirer. Since we are investigating how shareholder gains from acquisitions are related to characteristics of the country of the target as well as characteristics of the acquirer, we include in our sample only subsidiary targets where the ultimate parent's country is the same as the subsidiary's country. The initial sample includes 45,875 acquisitions. We then limit the sample to public acquirers, which reduces the sample to 24,463 acquisitions. As we are only interested in deals that are important investments from the acquirer's perspective, we eliminate all deals where the value of the transaction reported by SDC is less 
than $1 \%$ of the acquiring firm's market value of equity two days before the announcement. The deal value is only available for 12,393 acquisitions and of these acquisitions only 9,036 have a deal value in excess of $1 \%$ of the acquiring firm's market value of equity. Finally, we need stock returns to estimate abnormal returns and eliminate an acquirer (target) from the sample if the acquirer (target) is involved in multiple acquisitions within a five-day window surrounding the announcement of the deal, which leaves us with 8,090 acquisitions. Using the same sample selection criteria for domestic acquisitions yields a sample of 29,324 acquisitions.

Our final sample contains 37,414 deals. Panel A of Table 1 shows how the sample is distributed over the sample period. The distribution through time of the domestic deals and cross-border deals differs somewhat. Both domestic and cross-border deals are represented disproportionately during the 1998-2000 merger wave. However, relatively more of the cross-border deals occur after the merger wave and relatively fewer occur before the merger wave compared to domestic deals. In particular, $47.34 \%$ of the cross-border deals occur after 2000, compared to only $41.47 \%$ for domestic deals. The correlation between the number of deals per year during the sample period for cross-border and domestic deals is $86 \%$.

Panel B of Table 1 shows some interesting differences between the industry representation of crossborder and domestic deals using the ten SIC-based main industry classifications (e.g., Kahle and Walkling, 1996). For example, while manufacturing represents the industry with the most domestic and cross-border deals, the representation of more than $46.2 \%$ for cross-border deals is substantially larger than the $27.8 \%$ for domestic deals. In contrast, cross-border deals (10.3\%), compared to domestic deals (23.0\%), are much less likely to involve financials, which is likely due to regulatory issues. After manufacturing, services represent the largest industry for both domestic and cross-border deals.

Finally, Panel C shows the distribution of the sample across acquirer nations. While the U.S. accounts for more than half of the domestic transactions (55.7\%), only $23.3 \%$ of the cross-border transactions have a U.S. firm as the acquirer. In fact, the U.K. has a slightly higher representation (24.2\%) in the crossborder sample than the U.S. In contrast to the U.S., the U.K. represents a larger fraction of the cross- 
border transactions than of the domestic transactions (17.9 percent). In terms of cross-border transactions, the top ten countries in terms of sample representation are respectively U.K., U.S., Canada, Australia, France, Sweden, Ireland, Germany, the Netherlands, and Singapore. These ten countries, out of a total of 56 countries in the sample with at least one firm making a cross-border acquisition, represent nearly $80 \%$ of the cross-border deals in our sample.

\subsection{Abnormal returns}

Stock returns are obtained from Datastream. All our analysis uses dollar returns. We use SEDOL from SDC to merge with Datastream to obtain event returns for the acquirer. SDC reports a Primary SEDOL and an Ultimate Parent SEDOL as firm identifiers. If the primary SEDOL matches to Datastream we use the Primary SEDOL, otherwise we use the Ultimate Parent SEDOL.

Estimating acquirer stock-price reactions across 61 countries presents several challenges. A possible approach is to follow the traditional approach carried on for U.S. acquisitions and estimate the market model at the country level to estimate abnormal returns over a three-day window. Some of the studies discussed in Section 2 do exactly that (e.g., Ahearn, Daminelli, and Fracassi, 2010; Chari, Ouimet, and Tesar, 2010). There are two potential problems with such an approach. First, the number of firms differs sharply across countries, so that in some countries the acquirer might be an extremely large fraction of the market portfolio. For instance, Statoil ASA of Norway acquires North American Oils Sands Corp. Statoil ASA's market capitalization represents $27.80 \%$ of the market portfolio of Norway. In such a case, the acquirer abnormal return would be pulled to zero because of the weight of the firm in the country market portfolio. To account for this issue and to make abnormal returns comparable across countries, we use a market model where the proxy for the market return is a proxy for the world market portfolio. Second, an acquisition announcement may take place first in the country of the target when the market is closed in the country of the acquirer or may take place in the country of the acquirer when the country of the target is closed for business. Further, stock market liquidity differs across countries and so do regulations for disclosure and stock trading. Differences in microstructure and disclosure could lead to a lag in the extent 
to which the market reacts to an acquisition in some countries. For instance, during our sample period, some countries stop trading in a stock for the day after it has moved by some percentage (i.e., South Korea). Consequently, the announcement effect may be spread over several days. To allow for enough time to incorporate the announcement information, we use a five-day announcement window instead of a more standard three-day window to estimate the cumulative abnormal return (CAR).

The parameters for the estimation of the market model are estimated over the period starting 205 days to 6 days prior to the announcement. We use the world index from Datastream as the regressor in the market model. All event returns are winsorized at the $0.5 \%$ level and the $99.5 \%$ level. ${ }^{3}$ We examine the robustness of our average CAR estimates to alternative specifications of the market model. In particular, we use the country index for event returns and also implement a method where we use the country index only if the country index is available and the market cap of the firm is less than $5 \%$ of the total market cap of the country index and the world index otherwise. Our estimates of average CARs are not affected by these choices.

\subsection{Country and firm-level data}

The first group of country-level governance variables includes the anti-self-dealing index (ANTI_SD) from Djankov et al. (2008), the anti-directors index (ANTI_DIR) from La Porta et al. (1998) as revised in Djankov et al. (2008), and private and public enforcement indices of securities laws (SECLAW_PRIVATE; SECLAW_PUBLIC) from La Porta et al. (2006). The literature, including Rossi and Volpin (2004), often uses the product of the anti-director rights index and the rule of law index (RULE_LAW), which measures the extent to which laws are enforced, from La Porta et al. (1998). This product is interpreted in the literature as a measure of shareholder protection (SHARE_PROTECT), and we do the same. We use an index from La Porta et al. (1998) measuring the quality of fiscal-year 1990 annual reports on their disclosure of accounting information (ACCOUNT) and an index of the quality of disclosure (JM_DISC) developed by Jin and Myers (2006). We also use the measure of creditor rights

\footnotetext{
${ }^{3}$ We correct for Datastream return errors based on the recommendations in Ince and Porter (2006).
} 
(CREDITOR_RIGHTS) from Djankov et al. (2007). While the existing literature on cross-border acquisitions has focused on shareholder rights indices, the FDI literature has shown that FDI flows are higher towards countries with poorer creditor rights (see Razin and Sadka, 2007). The argument in that literature is that foreign investors have more of an advantage over local firms in countries with poor creditor rights because they have better access to funding. We would therefore expect acquirer returns to be positively related to the creditor rights of the country of the acquired firm and negatively related to the creditor rights of the target's country. We expect that higher values for these indices in the acquirer's country are associated with higher stock-price reactions as better investor protection makes it harder for insiders to expropriate investors through the use of acquisitions or from the gains created by acquisitions. We would expect the opposite result for the target country's index if a firm from a country that protects investor rights can better export the advantages resulting from better investor protection, for instance by having a lower cost of capital.

For the second group of country-level governance proxies, we use the country-level indicators of KKM. These indicators are obtained from combining several hundred individual variables measuring political stability, government effectiveness, regulatory quality, enforcement of the rule of law, corruption, and the extent to which a country's citizens are able to participate in selecting their government. They vary annually since 1997. We use the index for the year of the acquisition announcement or 1997 if the acquisition takes place earlier. We follow Kaufman et al. (2008) and consider the mean of the six variables for each country (WDI_GOV_AVG). We also use the scores for the control of corruption (CONTROL_CORR), government effectiveness (GOVT_EFFECT), political stability (POL_STAB), regulatory quality (REG_QUALITY), rule of law (RULELAW_WGI), and voice and accountability (VOICE_ACCT). ${ }^{4}$ Again, we would expect acquirer returns to increase with the governance indices of the acquirer's country and decrease with the governance indices of the target's country.

\footnotetext{
${ }^{4}$ Note that RULE_LAW used to create the variable SHARE_PROTECT is different from the RULELAW_WGI variable. See the Appendix for a detailed description of these variables.
} 
We follow Bhattacharya and Daouk (2003) and define indicator variables equal to one if, respectively, insider trading laws (IT_LAW) and enforcement actions of insider trading laws (IT_ENF) are in place at least one year prior to the acquisition announcement year and zero otherwise. We would expect less insider trading to be associated with higher stock-price reactions in absolute value since the element of surprise in acquisition announcements would be higher.

Other country-level variables measure economic and financial development as well as the performance of markets in a country. Doidge, Karolyi, and Stulz (2006) show that firm-level governance measures are more effective with greater financial and economic development. We include the Gross Domestic Product (GDP_PCAP) per capita based on the World Development Indicators (WDI) dataset from the World Bank. GDP per capita is measured in 2007 dollars. Also, we construct a ratio of the aggregate market capitalization of the equity of publicly listed companies to the GDP of that country (MKTCAP_GDP) and a turnover ratio equal to the ratio of the annual dollar volume to the total market capitalization (CRTY_STK_TURNOVER). We would expect firms to be more valuable and to have more resources when the domestic market has done well in dollars. Trailing one-year stock returns per country (CTRY_RET_1YR) are collected from Datastream. Note that since we are considering dollar returns, a country's stock index could perform well because the country's stock market increased in value in local currency or because the local currency appreciated. Consequently, our stock returns measure subsumes the foreign exchange effect that some papers discussed earlier have shown to affect target returns and the frequency of cross-border acquisitions. One of the best-known theoretical papers on cross-border acquisitions, Adler and Dumas (1975), focuses on the role of such acquisitions in arbitraging barriers to portfolio investment. Consequently, we use a measure of such barriers. We would expect acquirers to gain more from acquisitions in countries with barriers to international investment and we would expect acquirers to have an advantage if they come from a country that has no such barriers. Bekaert (1995) and Edison and Warnock (2003) consider a measure based on the ratio of the market capitalization of the constituent firms comprising the International Finance Corporate (IFC) Investable Index to those that 
comprise the IFC Global index for each country (LIB_INTENSITY_AVG). We update this index annually, but it does not vary over the sample period for developed countries.

We use Compustat Global for firm-level characteristics (except for insider ownership for which we use Worldscope) and SDC for deal-level characteristics. Firm-level characteristics as well as deal size are measured in dollars. Requiring firm-level characteristics reduces our sample by $23 \%$. We are especially interested in the issue of whether firm-level governance characteristics reduce the importance of countrylevel governance. This is an issue that has been studied extensively in the literature. Doidge, Karolyi and Stulz (2007) find an extremely large country-level fixed-effect in firm-level governance for lessdeveloped countries. We use two firm-level governance measures. First, we use insider ownership from Worldscope measured as the percentage of closely held shares relative to the total shares outstanding (INSIDEPCT). The theoretical literature shows that one would expect insider ownership to be higher in countries with worse investor protection, so that insider ownership would mitigate the adverse impact of poor investor protection. La Porta et al. (2002) provide evidence in support of this prediction. The limitations of the Worldscope insider ownership data are well-known (see Dahlquist et al., 2003). However, there is no substitute for this data that has close to the same coverage. We also include indicator variables for whether non-U.S. acquirers have an ADR program (ADR). The literature shows both theoretically and empirically that ADR programs are a way for foreign corporations to rent U.S. laws and institutions (see Karolyi (2010) for a review of the literature).

The Appendix of the paper provides a detailed description of the country-level and firm-level variables we use.

\section{Gains to shareholders from acquisitions: Domestic versus cross-border acquisitions}

In this section, we assess whether cross-border acquisitions create wealth for acquiring-firm shareholders and whether the wealth they create differs from domestic acquisitions. Such an inquiry is important both generally and for the investigation of our paper. As discussed in Section 3, there is a large literature that assesses the benefits from international diversification at the firm level. One way to assess 
whether international diversification is valuable is to compare the gains to acquiring-firm shareholders from domestic acquisitions to those from cross-border acquisitions. In the context of our study, it is important to assess whether shareholders make gains from cross-border acquisitions to better evaluate our later results. If stock-price reactions were insignificant across cross-border acquisitions, abnormal returns might be too noisy to assess their relation to country characteristics with precision.

Table 2 shows the estimates for stock-price reactions to domestic and cross-border reactions. Average abnormal returns are statistically significant at the one-percent level for all types of acquisitions, except for the cross-border acquisitions of public targets paid for with stock, which is significant at the fivepercent level. In our analysis we focus on the results for the full sample and for the following subsamples: Public targets paid for with cash, public targets paid for with stock, subsidiary targets paid for with cash, private targets paid for with cash, and private targets paid for with stock. We do not provide a separate analysis for acquisitions for which the means-of-payment is mixed or unknown, but these acquisitions are included in the whole sample analysis.

For the whole sample, the average stock-price reactions for domestic and cross-border acquisitions are astoundingly similar, $1.42 \%$ versus $1.50 \%$. Obviously, the difference in the stock-price reaction between these two types of acquisitions is not significant. We consider next the stock-price reaction to different types of acquisitions. We find that acquisitions of public firms for cash represent $5.20 \%$ of the domestic acquisitions and $9.30 \%$ of the cross-border acquisitions. Perhaps not surprisingly, acquisitions of public firms for cash benefit the acquiring-firm shareholders. However, they benefit acquiring-firm shareholders significantly more with cross-border acquisitions than with domestic acquisitions. The difference in the stock-price reaction between domestic and cross-border acquisitions is $0.56 \%$ and is significant at the ten-percent level. In contrast, acquisitions of public firms for stock are over three times more likely for domestic acquisitions than cross-border acquisitions (7.47\% versus $2.30 \%)$. This finding is not surprising as it is also observed in several of the papers discussed in Section 2. Acquisitions of public firms paid for with stock have negative stock-price reactions, whether they are domestic or crossborder. The average abnormal return for cross-border acquisitions is $-2.02 \%$ in contrast to the average 
abnormal return for domestic acquisitions of $-1.18 \%$. The difference between the two average abnormal returns is not significant.

All types of acquisitions involving subsidiaries or private firms have significant positive abnormal returns. Such a finding is not surprising in light of the existing literature for acquisitions in the U.S. (see e.g., Fuller et al., 2002; Moeller et al., 2004, 2005). The frequency of subsidiary acquisitions is similar for cross-border acquisitions (19.90\%) and domestic acquisitions (21.20\%). The average abnormal returns for these two types of acquisitions are almost the same at respectively $1.71 \%$ and $1.66 \%$. The frequency of cross-border acquisitions of private firms for cash is about one third higher than the frequency of domestic acquisitions of private firms for cash (32.89\% compared to 24.91\%). Again, there is no meaningful difference in abnormal returns. Finally, as for acquisitions of public firms with stock, acquisitions of private firms with stock in cross-border acquisitions are infrequent. Only $4.68 \%$ of the cross-border acquisitions are acquisitions of private firms paid for with stock, which is roughly half the frequency of domestic acquisitions of private firms paid for with stock. The average abnormal return of such domestic acquisitions, $2.80 \%$, is insignificantly higher than the average abnormal return for comparable cross-border acquisitions, 2.59\%. With the large number of observations, all differences in relative frequencies between domestic and cross-border deals for the various sub-samples are significant at the one-percent level.

\section{Gains to acquiring-firm shareholders and country characteristics}

In this section, we investigate the relation between acquirer shareholder returns and the acquirer's country governance and investor protection characteristics as well as its economic and financial development. As Doidge, Karolyi and Stulz (2007) show, there are important reasons why firm-level governance is more effective when economic development and financial development are higher. However, in addition and perhaps more importantly, greater economic development and financial development could offer advantages to firms in making cross-border investments as they can draw on 
better resources if globalization is limited because of cross-country differences as discussed in Stulz (2005). For instance, it might be easier for firms from more financially developed countries to raise funds.

Two important issues need to be addressed before we can proceed to our regression analysis. First, it is known that firm and deal characteristics are related to stock-price reactions to acquisitions. For instance, we know that acquirer returns fall with acquirer size (see Moeller et al., 2004) and increase with acquirer leverage (see, e.g., Maloney, McCormick, and Mitchell, 1993). An important issue is therefore whether we should control for such characteristics. Second, the literature shows that stock-price reactions differ across types of acquisitions. This raises the question of whether we should consider the stock-price reactions to all acquisitions in a country or only consider stock-price reactions for each type of acquisitions. We explain how we resolve these issues next before turning to regressions.

The problem with controlling for firm and deal characteristics in regressions that attempt to explain the stock-price reaction to acquisitions across countries is that both firm and deal characteristics are endogenous to country characteristics. In a U.S. study, all firms have an equal opportunity to choose to proceed with a hostile offer or to proceed with a tender offer. However, in a cross-country study, firms in some countries will be limited in their ability to choose some deal characteristics. Similarly, firms are larger in some countries than others and differences in firm size across countries are often attributed to differences in institutions (see Kumar, Rajan, and Zingales, 2002). Yet, we know within the U.S. that large firms generally make acquisitions that have lower stock-price reactions. Hence, controlling for size, we might reach a different conclusion about the impact of institutions on the gains from acquisitions, but we would then ignore that part of the effect of institutions might work through size. We therefore choose to focus on regressions that have purely exogenous variables. In these regressions, the variables are country characteristics and indicator variables for a firm's industry and its calendar year. We then discuss which results are affected when we control for firm and deal characteristics. Specifically, at the deal level we control for relative size, whether the deal is classified as hostile, whether the deal is classified as a tender offer, and the worldwide liquidity of the market of the assets of the target (see e.g., Schlingemann et al., 2002). Our firm-level control variables include the natural logarithm of the market value of the 
acquirers' equity two days prior to the announcement, Tobin's Q (defined as the market value of assets divided by the book value of assets, where the market value of assets is the book value of assets minus the book value of equity plus the market value of equity), the operating cash flow divided by the book value of assets, and the market value measure of leverage (debt divided by the market value of assets).

As already discussed, acquisition returns are positive and significant for acquisitions of private companies and negative and significant for acquisitions of public companies paid for with equity. Consequently, if a country's firms make relatively more cross-border acquisitions of public firms paid for with equity, the stock-price reaction to acquisitions, everything else equal, will be worse in that country. This outcome raises a concern. There is a substantial literature that shows that firms that pay for acquisitions with equity signal to the market that their equity is overvalued (see e.g., Moeller et al., 2007). As a result, conditional on the market assessing the equity's value correctly, an acquisition might increase shareholder wealth even though the stock-price reaction is negative. This issue would suggest looking at acquisition types separately. However, this approach also suffers from a problem, which is that acquisition types are most likely endogenous to country characteristics since there is evidence (discussed in Section 2) that investors are reluctant to accept shares in payment for an acquisition when the shares trade in a country with poor governance.

A constant issue with research using country characteristics is that many of these country characteristics tend to be highly correlated, so that multicollinearity may make it difficult to assess the effect of independent variables in multiple regressions. We therefore start in Section 5.1. with estimating regressions with one country characteristic at a time, while controlling for calendar year and the industry of the acquirer. Next, in Section 5.2, we turn to regression analysis where we use multiple country characteristics for the bidder and the target in the same specification to assess whether a country characteristic is significant in Section 5.1. because it proxies for other country characteristics. In all regressions, we use the country characteristic for the acquiring firm as well as the same characteristic for the target. This approach allows us to assess how target country characteristics affect acquirer returns, but it also makes sure that if there is strong correlation among target and acquirer country characteristics, our 
assessment of the relation between acquirer returns and acquirer country characteristics is not biased. Finally, we cluster the residuals by country.

\subsection{Regressions using one country characteristic at a time}

The regression estimates are presented in Table 3. For each country characteristic, we show the coefficient on the country characteristic for the acquirer's country and for the target's country, as well as the number of observations and the adjusted R-squared of the regression. The first three country characteristics we consider are, respectively, the anti-self-dealing index (ANTI_SD), the anti-director index (ANTI_DIR), and the product of the anti-director index and the rule of law index (SHARE_PROTECT). We find no evidence that these indices are associated with acquirer returns for the whole sample. However, acquirer returns for cash acquisitions of public firms increase as the anti-selfdealing index of the acquirer country increases and as the anti-self-dealing index of the target country decreases. This pattern that a country characteristic has opposite effects depending on whether it is a characteristic of the acquirer's country or of the target's country is observed a number of times in the table. The coefficients are economically significant as a one standard deviation increase in the anti-selfdealing index is associated with an increase in the abnormal return of almost half a percentage point. The negative relation between abnormal returns and the anti-self-dealing index for acquisitions of public firms paid for with equity raises the possibility that a higher governance country has a higher quality information environment, so announcements of equity offers have greater signaling value. The anti-selfdealing index of the acquirer's country is not significant for other acquisition types. Acquirers gain more from acquisitions in countries where the anti-director index is lower for acquisitions of public firms paid for with equity and is insignificant for the whole sample and all other types of acquisitions. Acquirer returns fall with the anti-director index of the target's country for the whole sample. Finally, we find that the product (SHARE_PROTECT) of the anti-director index and the rule of law index is never significant.

There is no evidence that the creditor rights index (CREDITOR_RIGHTS) is correlated with acquirer returns. Interestingly, strong creditor rights in the target country are associated with lower gains for the 
acquiring firm, a finding that is consistent with the predictions of Razin and Sadka (2007). They argue that acquirers have an advantage if they have cheaper access to funds than firms in the target country because of better creditor rights in their home country. The securities law indices (SECLAW_PRIVATE; SECLAW_PUBLIC) are not related to the acquirer gains at all. The final index we consider in this group of indices typically associated with investor protection is an index of accounting transparency (ACCOUNT). We find that the index of the acquirer country is positively associated with acquirer gains and the index of the target is negatively associated with these gains for acquisitions of public firms for cash. We also use the quality of disclosure index (JM_DISC) of Jin and Myers (2006). The coefficient on that index is never significant for acquirer returns (not reproduced in the table).

After considering indices that are related to investor protection, we turn to the World Bank governance indicators. The first index we consider is related to the control of corruption (CONTROL_CORR). We find that acquirers from countries that control corruption better gain more from acquisitions for the whole sample and for cash acquisitions of public firms; further, acquirers gain more for the whole sample and for cash acquisitions of public firms when the target country controls corruption less. We obtain similar results using World Bank governance indicators for government effectiveness (GOVT_EFFECT), political stability (POL_STAB), regulatory quality (REG_QUALITY), rule of law (RULELAW_WGI), and voice (VOICE_ACCT). Not surprisingly, therefore, we also find these results when using the average governance index (WDI_GOV_AVG). The standard deviation of the average governance index across the whole sample is 0.369 . As a result, an increase of one standard deviation in the average governance index increases the stock-price reaction to cash acquisitions of public firms by 66 basis points and increases the stock-price reaction for the whole sample by 23 basis points. Another way to evaluate the economic significance of a change in the average governance index for the acquirer's country is that an increase of one standard deviation increases the acquirer's gain by $14.97 \%$ for the whole sample and by $60.65 \%$ for acquisitions of public firms paid for with cash.

We then consider two variables that measure, respectively, whether a country has a law limiting insider trading (IT_LAW) and whether that law is enforced (IT_ENF). Acquirer country enforcement has 
a positive significant coefficient for the whole sample while target country enforcement has a negative significant coefficient for the whole sample. The only significant coefficient for the existence of a law is a negative significant coefficient for the indicator for the acquirer's country for stock acquisitions of public firms. A possible explanation for this result is that the signaling effect of an offer to acquire a public firm for stock might be stronger in countries with less leakage due to insider trading.

The next four variables are related to the economic and financial situation of the country of the acquirer and target. We find no evidence that GDP per capita (GDP_PCAP) is related to acquirer gains in acquisitions, which might appear surprising in light of the findings of Chari et al. (2010). However, emerging countries have a number of common characteristics, so that acquirer returns from acquisitions in such countries might be higher because they have lower country governance rather than because they have lower GDP per capita. Greater stock market capitalization of the acquiring country (MKTCAP_GDP) is unrelated to acquisition gains except for a negative coefficient for acquisitions of private firms paid for with equity. The stock market capitalization of the target country has a negative coefficient for the whole sample. Stock market turnover of the acquirer's country (CTRY_STK_TURNOVER) has a positive coefficient for acquisitions of public firms paid for with equity and a negative coefficient for acquisitions of subsidiaries. The target's country stock market turnover is never significant. We then use a country's stock return in the year preceding the acquisition (CTRY_RET_1YR). This variable is never significant for the country of the acquirer; the stock return of the country of the target has a positive significant coefficient for stock acquisitions of public firms. Lastly, we consider the impact of the liberalization intensity index (LIB_INT_AVG). In interpreting the results for this variable, it is important to be aware that relatively few countries in the sample have acquisitions made when their liberalization intensity index is below one (only four acquisitions of public firms paid for with equity and only 40 acquisitions of public firms paid for with cash). The index has a positive significant coefficient for acquisitions of public firms, but a negative significant coefficient for acquisitions of subsidiaries. The coefficient is not significant for other types of acquisitions. This evidence would suggest that acquirers of countries with no barriers to international portfolio investment 
have higher returns when they acquire public firms. The index for the target country is not significant except for acquisitions of private firms paid for with equity. The Adler and Dumas (1975) theory would imply that acquirers would gain more from acquisitions in countries that have barriers to international investment. None of our results are consistent with that prediction.

Finally, we consider regressions with firm governance characteristics. We find that acquirer abnormal returns increase significantly with insider ownership (INSIDE_PCT) for the whole sample and all acquisition types but acquisitions of private firms. The standard deviation of insider ownership across our sample is $23.16 \%$. As a result, a one standard deviation increase in insider ownership increases the stockprice reaction by 27 basis points for the whole sample and by 59 basis points for the sample of acquisitions of public firms for cash. Roughly, therefore, the impact on the stock-price reaction of a one standard deviation increase in insider ownership is approximately the same as the impact of a one standard deviation increase in the average country governance index. Restricting the sample to foreign firms only, we use an indicator variable for whether a firm has an ADR program (ADR). For the whole sample, the existence of an ADR program is negatively associated with the acquirer return and positively associated with the existence of an ADR program for the target firm. Acquirers of public firms with ADR programs have marginally lower returns (p-value of 0.10 ) when they make acquisitions financed with equity using the sample of non-U.S. acquirers and targets. This result may simply reflect the better information environment of ADR firms (e.g., Bailey, Karolyi, and Salva, 2006), so that issuance of equity has more signaling value.

\subsection{Regressions using multiple country characteristics}

We now turn to multiple regressions. The concern with the regressions of Table 3 is that country governance could derive its significance from its correlation with other variables. Further, we know from our earlier discussion that there are good reasons for financial development and economic development, which are correlated with country governance, to affect abnormal returns. For instance, even though GDP per capita is not significant in Table 3, it could be that country governance is significant only because it 
partly proxies for GDP per capita. We therefore estimate regressions with country governance where we control for economic and financial development. Our proxy for economic development is GDP per capita; the proxy for economic development is the ratio of stock market capitalization to GDP. We see in Panel A of Table 4 that, when controlling for economic and financial development, country governance remains significant for the whole sample and for cash acquisitions of public firms, but also becomes significant for private firm acquisitions paid for with cash.

The regression estimates of model (1) are for the whole sample and show that country governance remains significant when we control for financial and economic development. It is interesting to note that while GDP per capita is not significant in Table 3, GDP per capita of the target country is positive and significant for the whole sample in Table 4. This is further evidence that acquisitions in emerging markets may have higher acquirer returns not because these countries are poorer, but because they have poorer governance.

We estimate the same regression for each type of acquisition in models (2) to (6) of Panel A of Table 4. The coefficient on country governance of the acquiring firm is significantly positive for acquisitions of public and private firms paid for with cash. The country governance of the target firm is significantly negative for acquisitions of public firms paid for with cash and of private firms paid for with equity. GDP per capita of the target has a positive significant coefficient for acquisitions of subsidiaries and acquisitions of private firms. There is no evidence that acquirers gain more from acquisitions in countries with lower GDP per capita.

Though we do not reproduce the results in a table, we also investigate regressions where we use accounting transparency (ACCOUNT), the securities law index (SEC_LAW), and the anti-self-dealing index (ANTI_SD). In these regressions, accounting transparency of the acquirer has a positive significant coefficient and accounting transparency of the target country has a negative significant coefficient for the whole sample. Further, the anti-self-dealing index of the acquirer's country has a significant negative coefficient and the coefficient on securities laws of the target is significantly positive. The negative coefficient on the anti-self-dealing index is solely due to acquisitions of public firms paid for with equity. 
In another set of regressions, we use as country characteristics the country stock market return, the index of political stability, and the level of GDP as a proxy for country size. We find that the country return of the target is positively significant and the political stability of the target is negatively significant. The coefficient on the country return of the target is driven by acquisitions of public firms paid for with stock.

We re-estimate the regressions of Table 4 with the product of the anti-director index and the rule of law index (SHARE_PROTECT) for both the target and acquirer added as explanatory variables, but do not report these regressions in a table. For the whole sample, the coefficient on SHARE_PROTECT is insignificant for the acquirer's country and for the target's country. The acquirer's country coefficient is negative and significant in acquisitions of public firms for equity. The target's country coefficient is positive and significant in acquisitions of private firms for cash.

Table 3 shows that bidder insider ownership is positively related to bidder returns. We re-estimate the regressions of Panel A of Table 4 with insider ownership of the acquirer (INSIDE_PCT) as an explanatory variable. Doing so reduces the size of the whole sample by a quarter. Yet, as shown in Panel B of Table 4, the coefficients on the country governance indices are significant and the ownership variable has a coefficient of 0.0149 that is significant at the one-percent level for the whole sample. The coefficient on insider ownership is positive and significant for all types of acquisitions except acquisitions of private firms. The coefficient on acquirer-country governance is positive and significant in all cases except for acquisitions of public firms paid for with equity and of subsidiaries.

Since La Porta, Lopez-de-Silanes, Shleifer, and Vishny (2002), the literature has examined whether insider ownership mitigates the adverse impact of poor laws or poor country governance. We find some evidence (but do not tabulate it) that greater insider ownership reduces the adverse impact of worse country governance. We estimate regressions with acquirer country governance, acquirer insider ownership, and an interaction between insider ownership and country governance. If insider ownership mitigates the adverse impact of poor country governance, we expect that interaction to have a negative coefficient. For acquisitions of private firms, we find that all three coefficients - i.e., the signs on ownership, governance, and the interaction - have the predicted sign. For the whole sample and the 
acquisitions of public firms paid for with cash, all three variables have the predicted sign, but the interaction is never significant. We repeat the exercise with the anti-director index. The interaction is negative and significant only for acquisitions of public firms with equity. In all other cases, the interaction is insignificant.

We next estimate all the regressions discussed so far controlling for the firm and deal characteristics described earlier. We do not report these regressions in a table. We lose about one quarter of observations in the regressions that use these characteristics. For the whole sample, we find that the acquisition return increases in the relative size of the acquisition, falls in the size of the acquirer, and falls if the acquisition is a tender offer. The results are consistent with results for U.S. domestic acquisitions and therefore firm and deal characteristics do not appear to play a significantly different role for cross-border acquisitions. For the various types of acquisitions, the signs of these coefficients are generally consistent, but not always significant. No other deal or firm characteristic is consistently significant. The estimates for the country characteristics are generally consistent with the estimates discussed earlier, but they sometimes lose significance as firm characteristics are correlated with country characteristics for reasons discussed earlier.

\section{How important are countries in acquirer returns?}

We turn to assessing the economic importance of global versus country effects. We have seen that the country governance of the acquiring (target) firm is positively (negatively) related to the acquirer return and these results are economically significant. In these regressions, we use as regressors year and industry indicator variables as well as country characteristics. We therefore investigate the relative explanatory power of year and industry indicator variables compared to country characteristics. Because the coefficients on year and industry indicator variables are determined globally, we consider them to represent global factors in the determination of acquirer returns.

In Table 5, we present regressions using year, industry, and country indicator variables for the whole sample and for each acquisition type. By definition, the coefficient of the acquirer country indicator 
variable measures the impact of the acquirer's country on the acquisition return. We are interested in the explanatory power of the indicator variables. This is best measured by the R-squared of regressions that have different subsets of these explanatory variables. We estimate five regressions for each sample: calendar year dummies only, country dummies only, industry dummies only, target country dummies only, and all indicator variables in one regression. We only include countries and industries with five acquisitions at least. We only show the R-squared of each regression, the $p$-value for an F-test of the joint significance of the indicator variables, and the number of observations. The first set of regressions in Table 5 is for the sample as a whole. It is immediately apparent that together the year of an acquisition and the industry of the acquirer explain more than the country of the acquirer. However, the country of the target explains about the same as all these variables together. It follows that the global effects dominate the acquirer country effects.

We estimate the same regressions for each type of acquisition as well. In all cases except for acquisitions of private firms paid for with cash, year and industry indicator variables explain more than acquirer country indicator variables. Further, it is always the case that the country of the target is more informative than the country of the acquirer. Strikingly, for acquisitions of public firms paid for with cash none of the sets of indicator variables are significant. For acquisitions of public firms paid for with stock, the industry indicator variables are jointly significant. The year, industry, and target country indicator variables are each jointly significant for acquisitions of subsidiaries, but the acquirer country indicator variables are not jointly significant. Similar results hold for acquisitions of private firms for cash. Finally, with acquisitions of private firms for equity, the indicator variables for the acquirer's country are jointly significant, but the year and industry indicator variables are not significant.

Another way to identify the existence of a global effect on acquirer returns is as follows. For each sample, we measure the average acquirer return for acquisitions made in other countries in the same year. We then estimate a regression of acquirer returns on the acquirer returns for the same type of acquisitions in other countries during the same year, which we refer to as GLOBAL_EFFECT. The results for this analysis are reported in Table 6. The coefficient on GLOBAL_EFFECT is positive and significant for the 
whole sample and for the sub-samples of acquisitions of private firms and subsidiaries. For the whole sample, a one standard deviation increase in the average acquirer CAR outside a country leads to an increase in the average CAR in the country of 24 basis points. The coefficient is insignificant for acquisitions of public firms. These results show that the acquirer gains in a given year are higher when the gains made on similar acquisitions by acquirers in other countries are higher, so that there is a global factor in the gains from acquisitions. The regression models in Table 6 include industry indicator variables (not reported), but the results are robust to excluding these.

\section{How important are countries in cross-border acquisition intensity?}

We have shown that country governance has an economically significant effect on the returns from cross-border acquisitions. We have also shown that global effects play an important role in acquirer returns. In this section, we examine whether country governance affects the frequency of acquisitions in our sample. The sample we have used so far requires the deal value to be known. As we saw, this sample reduces the sample size considerably. To evaluate the determinants of the frequency of acquisitions, this sample suffers from a selection bias. Therefore, we consider in this section a sample of acquisitions that does not require deal value to be reported in SDC as well as the restricted sample we have considered so far. The less restrictive sample includes acquisitions by private firms as well, but it only includes control acquisitions, so our results are not directly comparable with those of studies that include partial acquisitions. This sample is much larger as it includes 45,875 acquisitions. Slightly more than 21,412 of these acquisitions are by private firms.

We estimate regressions of the frequency of acquisitions relative to the number of listed firms in a country (effectively, the number of firms with returns on Datastream). Since these regressions are estimated using country-level data, we cannot use the industry indicator variable and therefore we only use calendar year indicator variables as our global variables. We use as our country variables the country governance index, GDP per capita, the index for liberalization intensity, the index for securities laws, the 
anti-self-dealing index, the country's market capitalization to GDP ratio, and the country's stock return in the previous year. We report the results in Table 7.

The first regression uses the sample without restrictions. We find a very strong effect of the country governance index (WDI_GOV_AVG) on the frequency of cross-border acquisitions. In contrast, none of the other variables are significant. Though we do not reproduce the results in the table, we also estimate model (1) without GDP per capita and without the country governance index. The country governance index has roughly the same coefficient when GDP per capita is not included in the regression. When the country governance index is not included, GDP per capita is significant at the $5 \%$ level with a coefficient of 0.0035 . These results suggest that when the country governance index is not included in the regression, GDP per capita proxies for that index. Strikingly, when we omit the country governance index the adjusted R-squared drops from 0.43 to 0.30 . In contrast, it essentially does not change when we omit GDP per capita. We also estimate the model without year indicator variables. When we do so, the coefficient on the country governance index is not affected. None of the other variables are significant. Model (2) is for the acquisitions that meet the sample requirements of the earlier section. We see again that the country governance index is the only significant variable. However, the coefficient on that index is much lower. Again, GDP per capita has no explanatory power. We then estimate the regressions for the different acquisition types omitting the GDP per capita. The governance index is significant with a positive coefficient in each of the regression specifications. The stock market capitalization variable is significant and positive for acquisitions of public firms for cash. Finally, the country return is not significant for acquisitions of private firms and subsidiaries when we omit the year indicator variables (not reported in the table). The year indicator variables explain much less for acquisitions of subsidiaries and private firms paid for with cash. The adjusted R-squared falls by more than half when these variables are omitted for acquisitions of public and private firms paid for with stock. Furthermore, the adjusted R-squared falls by almost $40 \%$ for acquisitions of public firms paid for with cash. 
These regressions show that the country governance is an important determinant of controlacquisition frequency. It affects all types of acquisitions and no other widely used country characteristic is significant in our sample.

\section{Conclusion}

In this paper, we examine how the gains to shareholders from investments are related to country and firm-level governance using a sample of cross-border acquisitions from 61 countries from 1990 to 2007. We find that the gains to acquirers increase with the acquirer's country governance and fall with the target's country governance. Further, firms in countries with better country governance make more acquisitions. In addition, the stock-price reaction to acquisition announcements increases with the acquirer's insider ownership but, to some extent, more so in countries with weaker governance. Whereas our governance variables have an economically significant relation with acquirer returns showing that firms benefit from better country governance, we find no evidence that other country characteristics have a reliable systematic relation with acquirer returns across acquisition types. However, both the accounting transparency and the anti-self-dealing indices are positively related to the stock-price reaction to cash acquisitions of public firms and the coefficient estimates are highly significant.

Though country governance is an important determinant of stock-price reactions to acquisition announcements, we find that the importance of country characteristics is surprisingly limited. In particular, the year of an acquisition and the industry of an acquirer typically explain more of the abnormal return than the country of the acquirer. Since the coefficients on year and industry indicator variables are estimated across the whole sample, they reflect global factors. We find further evidence that global factors influence stock-price reactions in that acquirers in a country earn less through acquisitions of private firms and subsidiaries when acquirers in other countries earn less as well. All this evidence points to the fact that the market for cross-border acquisitions is a global market, but acquirers from countries with better governance have an intrinsic advantage in that market. 


\section{References}

Adler, Michael and Bernard Dumas, 1975, Optimal international acquisitions, Journal of Finance 30, 119.

Ahern, Kenneth, Daniele Daminelli, and Cesare Fracassi, 2010, Lost in translation? The effect of cultural values on mergers around the world, Working Paper, University of Michigan, Ann Arbor, MI.

Bailey Warren., G. Andrew Karolyi, and Carolina Salva, 2006, The economic consequences of increased disclosure: Evidence from international cross-listings, Journal of Financial Economics 81, 175-213.

Bekaert, Geert and Campbell Harvey, 1995, Time-varying world market integration, Journal of Finance, 50, 403-44.

Bhattacharya, Utpal and Hazem Daouk, 2002, The world price of insider trading, Journal of Finance 57, pp. 75-108.

Black, Bernard S., 2000, The first international merger wave (and the fifth and last U.S. wave), University of Miami Law Review, 799-818.

Bris, Arturo and Christos Cabolis, 2008, The value of investor protection: Firm evidence from crossborder mergers, Review of Financial Studies 21, 605-648.

Burns, Natasha, Bill B. Francis, and Hasan Iftekhar, 2007, Cross-listing and legal bonding: Evidence from mergers and acquisitions, Journal of Banking and Finance, 1003-1031.

Chari, Anusha., Paige P. Ouimet, and Linda L. Tesar, 2010, The value of control in emerging markets, Review of Financial Studies 23, 1741-1770.

Coffee, John C., 1999, The future as history: The prospects for global convergence in corporate governance and its implications, Northwestern University Law Review 93, 641-708.

Dahlquist, Magnus, Lee F. Pinkowitz René M. Stulz, and Rohan Williamson, 2003, Corporate Governance and the Home Bias, Journal of Financial and Quantitative Analysis 38, 87-110.

Djankov, Simeon, Caralee McLiesh, and Andrei Shleifer, 2007, Private credit in 129 countries, Journal of Financial Economics. 84, 299-329.

Djankov, Simeon, Rafael La Porta, Florencio Lopez-de-Silanes, and Andrei Shleifer, 2008, The law and economics of self-dealing, Journal of Financial Economics 88, 430-465.

Doidge, Craig, G. Andrew Karolyi, and René M. Stulz, 2004, Why do countries matter so much for corporate governance?, Journal of Financial Economics 86, 2007, 1-39.

Dos Santos, Marcelo B., Vihang Errunza and Darius Miller, 2008, Does corporate international diversification destroy value? Evidence from cross-border mergers and acquisitions, Journal of Banking and Finance 32, 2716-2724.

Doukas, John and Nickolaos Travlos, 1988, The effect of corporate multi-nationalism on shareholders' wealth: Evidence from international acquisitions, Journal of Finance 43, 1161-1175. 
Edison, Hali J. and Frank Warnock, 2003, A simple measure of the intensity of capital controls. Journal of Empirical Finance 10, 81-103.

Erel, Isil, Rose C. Liao, and Michael S. Weisbach. 2010, World markets for mergers and acquisitions, working paper, Dice Center for Financial Economics, Ohio State University, Columbus, OH.

Eun, Cheol, Richard Kolodny, and Carl Scheraga, 1996, Cross-border acquisitions and shareholder wealth: Tests of the synergy and internationalization hypotheses, Journal of Banking and Finance 20, 1559-1582.

Ferreira, Miguel A., Massimo Massa, and Pedro P. Matos, 2010, Shareholders at the gate? Institutional investors and cross-border mergers and acquisitions, Review of Financial Studies 23, 2010, 601-644.

Fuller, Kathleen, Jeffrey Netter, and Mike Stegemoller, 2002, What do returns to acquiring firms tell us? Evidence from firms that make many acquisitions, Journal of Finance 57, 1763-1794.

Harris, Robert S., and David Ravenscraft, 1991, The role of acquisitions in foreign direct investment: Evidence from the U.S. stock market, Journal of Finance, 825-844.

Jensen, Michael C., and William Meckling, 1976, Theory of the firm: Managerial behavior, agency costs, and ownership structure, Journal of Financial Economics 3, 305-360.

Jensen, Michael C. and Richard S. Ruback, 1983, The market for corporate control: The scientific evidence, Journal of Financial Economics 11, 5-50.

Jin, Li, and Stewart C. Myers, 2006, $\mathrm{R}^{2}$ around the world: New theory and new tests, Journal of Financial Economics 79, 257-292.

Kahle, Kathleen, and Ralph Walkling, 1996, The impact of industry classification on financial research, Journal of Financial and Quantitative Analysis 31, 309-335.

Karolyi, G. Andrew and Rose C. Liao, 2010, What is different about government-controlled acquirers in cross-border acquisitions?, unpublished working paper, Cornell University, NY.

Kaufmann, Daniel, Aart Kraay, and Massimo Mastruzzi, 2009. Governance matters VIII: Aggregate and individual governance indicators 1996-2008, Policy Research Working Paper Series 4978, The World Bank.

Kuipers, David K., Darius Miller, and Ajay Patel, 2009, The legal environment and corporate valuation: Evidence from cross-border takeovers, International Review of Economics and Finance 18, 552-567.

Kumar, K., Raghuram Rajan, and Luigi Zingales, 2002, What determines firm size?, unpublished working paper, University of Chicago, Chicago, IL.

La Porta, Rafael, Florencio Lopez-De-Silanes, and Andrei Shleifer, 2006, What works in securities laws?, Journal of Finance 61, 1-32.

La Porta, Rafael, Florencio Lopez-de-Silanes, Andrei Shleifer, and Robert W. Vishny, 1997, Legal Determinants of External Finance, Journal of Finance 52, 1131-1150. 
La Porta, Rafael, Florencio Lopez-de-Silanes, Andrei Shleifer, and Robert W. Vishny, 1998, Law And Finance, Journal of Political Economy 106, 1113-1155.

La Porta, Rafael, Florencio Lopez-De-Silanes, Andrei Shleifer, and Robert Vishny, 2002, Investor protection and corporate valuation, Journal of Finance 57, 1147-1170.

Maloney, Michael T., Robert E. McCormick, and Mark L. Mitchell, 1993, Managerial decision making and capital structure, Journal of Business 66, 189-217.

Martynova, Marina and Luc Renneboog, 2008, Spillover of corporate governance standards in crossborder mergers and acquisitions, Journal of Corporate Finance 14, 200-223.

Masulis, Ronald W., Cong Wang, and Fei Xie, 2007, Corporate governance and acquirer returns, Journal of Finance 62, 1852-1889.

Moeller Sara B., and Frederik P. Schlingemann, 2005, Global diversification and bidder gains: A comparison between cross-border and domestic acquisitions, Journal of Banking and Finance 29, 533564.

Moeller Sara B., and Frederik P. Schlingemann, and René M. Stulz, 2007, How do diversity of opinion and information asymmetry affect acquire returns?, Review of Financial Studies 20, 2047-2078.

Moeller, Sara B., Frederik P. Schlingemann, René M. Stulz, 2004. Firm size and the gains from acquisitions. Journal of Financial Economics 73, 201-228.

Olson, Mancur Jr., 1996, Big bills left on the sidewalk; Why some nations are rich and others poor, Journal of Economic Perspectives 10, 3-24.

Pinkowitz, Lee, René M. Stulz, and Rohan Williamson, 2006, Does the contribution of corporate cash holdings and dividends to firm value depend on governance? A cross-country analysis, Journal of Finance 61, 2725-2751.

Razin, Assaf, and Efraim Sadka, 2007, The role of information in driving FDI flows: Host-country transparency and source country specialization, European Economic Review.

Schlingemann, F.P., Stulz, R.M., Walkling, R.A., 2002, Divestitures and the liquidity of the market for corporate assets. Journal of Financial Economics 64, 117-144.

Rajan, Raghuram G. and Luigi Zingales, 2003, The great reversals: The politics of financial development in the 20th century, Journal of Financial Economics 69, 5-50.

Rossi, Stefano and Paolo Volpin, 2004 Cross-country determinants of mergers and acquisitions, Journal of Financial Economics 74, 277-304.

Shleifer, Andrei, and Daniel Wolfenzon, 2002, Investor protection and equity markets, Journal of Financial Economics 66, 3-27.

Stulz, René M., 1999, Globalization, corporate finance, and the cost of capital, Journal of Applied Corporate Finance 12, 8-25.

Stulz, René M., 2005, The limits of financial globalization, Journal of Finance 60, 1595-1638. 


\section{Appendix - Variable definitions and sources}

\begin{tabular}{|c|c|c|c|c|c|}
\hline Variable name & Definition and Source & $\begin{array}{l}\text { Acquirer, } \\
\text { Target, } \\
\text { or Deal }\end{array}$ & $\begin{array}{l}\text { Time- } \\
\text { varying }\end{array}$ & $\begin{array}{l}\text { Country } \\
\text { or Firm }\end{array}$ & $\begin{array}{l}\text { Data } \\
\text { Year }\end{array}$ \\
\hline ACCOUNT & $\begin{array}{l}\text { Index created by the Center for International Financial Analysis and } \\
\text { Research to rate the quality of } 1990 \text { annual reports on their disclosure } \\
\text { of accounting information. Source: La Porta et al. (1998). }\end{array}$ & Both & No & Country & 1990 \\
\hline ADR & $\begin{array}{l}\text { Indicator variable equal to one if the firm has a "dscode" listed in } \\
\text { Datastream and has an ADR and equal to zero if firm has dscode, but } \\
\text { does not have an ADR. Value is set to missing if firm does not have a } \\
\text { "dscode" (i.e. private). Source: Datastream. }\end{array}$ & Both & Annual & Firm & $\begin{array}{l}1990- \\
2007\end{array}$ \\
\hline ANTI_DIR & $\begin{array}{l}\text { Revised version of the Anti-Directors Index from La Porta et al. } \\
\text { (1998) with values from 0-6. The index is formed by adding one } \\
\text { when (i) the country allows shareholders to mail their proxy vote to } \\
\text { the firm, (ii) shareholders are not required to deposit their shares prior } \\
\text { to the general shareholders' meeting, (iii) cumulative voting or } \\
\text { proportional representation of minorities in the board of directors is } \\
\text { allowed, (iv) an oppressed minorities mechanism is in place, (v) the } \\
\text { minimum percentage of share capital that entitles a shareholder to call } \\
\text { for an extraordinary shareholders' meeting is less than or equal to } \\
10 \% \text { (the sample median), or (vi) shareholders have preemptive rights } \\
\text { that can be waived only by a shareholders' vote. Source: Djankov et } \\
\text { al. (2008). }\end{array}$ & Both & No & Country & 2003 \\
\hline ANTI_SD & Anti-self dealing index. Source: La Porta et al. (2006). & Both & No & Country & 2003 \\
\hline CREDITOR_RIGHTS & $\begin{array}{l}\text { Creditor rights aggregate score based on } 129 \text { countries' private credit. } \\
\text { Source: Djankov et al. (2007). }\end{array}$ & Both & No & Country & 2003 \\
\hline CTRY_RET_1YR & Trailing one-year country stock returns. Source: Datastream. & Both & Annual & Country & $\begin{array}{l}1990- \\
2007\end{array}$ \\
\hline CTRY_STK_TURNOVER & $\begin{array}{l}\text { Ratio of annual dollar volume to total market capitalization. Source: } \\
\text { World Bank. }\end{array}$ & Both & Annual & Country & $\begin{array}{l}1990- \\
2007\end{array}$ \\
\hline
\end{tabular}


Appendix - Continued

\begin{tabular}{|c|c|c|c|c|c|}
\hline Variable name & Definition and Source & $\begin{array}{l}\text { Acquirer, } \\
\text { Target, } \\
\text { or Deal }\end{array}$ & $\begin{array}{l}\text { Time- } \\
\text { varying }\end{array}$ & $\begin{array}{l}\text { Country } \\
\text { or Firm }\end{array}$ & $\begin{array}{l}\text { Data } \\
\text { Year }\end{array}$ \\
\hline GDP_PCAP & $\begin{array}{l}\text { Gross domestic product per capita measured in } 2007 \text { US dollars. } \\
\text { Source: World Development Indicators (World Bank). }\end{array}$ & Both & Annual & Country & $\begin{array}{l}1990- \\
2007\end{array}$ \\
\hline GOVT_EFFECT & $\begin{array}{l}\text { Government Effectiveness measures the quality of public services, the } \\
\text { quality of the civil service and the degree of its independence from } \\
\text { political pressures, the quality of policy formulation and } \\
\text { implementation, and the credibility of the government’s commitment } \\
\text { to such policies. Source: Kauffman et al. (2009) and World } \\
\text { Governance Indicators Data (World Bank). }\end{array}$ & Both & Annual & Country & $\begin{array}{l}1997- \\
2007\end{array}$ \\
\hline IT_LAW & $\begin{array}{l}\text { Indicator variable equal to one if the acquisition announcement year is } \\
\text { after the first year that insider trading laws were put into place in the } \\
\text { country. Source: Bhattacharya and Daouk (2002). }\end{array}$ & Both & Annual & Country & 2002 \\
\hline JM_DISC & $\begin{array}{l}\text { The disclosure index as defined in Jin and Meyers (2006). The index } \\
\text { is defined at the country level and updated for missing sample }\end{array}$ & Both & No & Country & $\begin{array}{l}1999- \\
2000\end{array}$ \\
\hline
\end{tabular}

countries based on the same methodology as in Jin and Myers (2006) using the Global Competitiveness Reports for 1999 and 2000. Higher values for the index measure more transparency. The index is based on the average scoring on two survey questions regarding the level and effectiveness of financial disclosure across the sample years 1999 and 2000. Source: Jin and Myers (2006).

LIB_INT_AVG

The intensity measure is based on the ratio of the market capitalization of the constituent firms comprising the IFC Investable index to those that comprise the IFC Global index for each country. The IFC Global index, subject to some exclusion restrictions, is designed to represent the overall market portfolio for each country, whereas the IFC Investable index is designed to represent a portfolio of domestic equities that are available to foreign investors. A ratio of one means that all of the stocks are available to foreign investors (see e.g., Bekaert (1995); Edison and Warnock (2003)). 
Appendix - Continued

\begin{tabular}{|c|c|c|c|c|c|}
\hline Variable name & Definition and Source & $\begin{array}{l}\text { Acquirer, } \\
\text { Target, } \\
\text { or Deal }\end{array}$ & $\begin{array}{l}\text { Time- } \\
\text { varying }\end{array}$ & $\begin{array}{l}\text { Country } \\
\text { or Firm }\end{array}$ & $\begin{array}{l}\text { Data } \\
\text { Year }\end{array}$ \\
\hline MKTCAP_GDP & $\begin{array}{l}\text { Ratio of market capitalization of listed domestic stocks in a country } \\
\text { and the gross domestic product of that country. Source: Datastream. }\end{array}$ & Both & Annual & Country & $\begin{array}{l}1990- \\
2007\end{array}$ \\
\hline REG_QUALITY & $\begin{array}{l}\text { Regulatory Quality measures the ability of the government to } \\
\text { formulate and implement sound policies and regulations that permit } \\
\text { and promote private sector development. Source: Kauffman et al. } \\
\text { (2009) and World Governance Indicators Data (World Bank). }\end{array}$ & Both & Annual & Country & $\begin{array}{l}1997- \\
2007\end{array}$ \\
\hline RULE_LAW & $\begin{array}{l}\text { Assessment of the law and order tradition in the country produced by } \\
\text { the risk-rating agency International Country Risk (ICR). The index is } \\
\text { based on the average of the months of April and October of the } \\
\text { monthly index and averaged for the years } 1982 \text { to 1995. The index } \\
\text { ranges between zero and ten. Source: La Porta et al. (1998). }\end{array}$ & Both & No & Country & $\begin{array}{l}1982- \\
1995\end{array}$ \\
\hline RULELAW_WGI & $\begin{array}{l}\text { Rule of Law measures the extent to which agents have confidence in } \\
\text { and abide by the rules of society, in particular the quality of contract } \\
\text { enforcement, the police, and the courts, as well as the likelihood of } \\
\text { crime and violence. Source: Kauffman et al. (2009) and World } \\
\text { Governance Indicators Data (World Bank). }\end{array}$ & Both & Annual & Country & $\begin{array}{l}1997- \\
2007\end{array}$ \\
\hline SHARE_PROTECT & $\begin{array}{l}\text { Measure of the effective rights of minority shareholders. This variable } \\
\text { is the product of ANTI_DIR and RULE_LAW divided by ten so that } \\
\text { values range between zero and six. }\end{array}$ & Both & No & Country & n.a. \\
\hline SECLAW_PRIVATE & $\begin{array}{l}\text { The private enforcement index is the arithmetic mean of their } \\
\text { disclosure index and burden of proof index. Following LaPorta et al. } \\
\text { (2004), measures of private enforcement are the most associated with } \\
\text { the development of markets. Source: LaPorta et al. (2004). }\end{array}$ & Both & No & Country & 2000 \\
\hline
\end{tabular}


Appendix - Continued

\begin{tabular}{|c|c|c|c|c|c|}
\hline Variable name & Definition and Source & $\begin{array}{l}\text { Acquirer, } \\
\text { Target, } \\
\text { or Deal }\end{array}$ & $\begin{array}{l}\text { Time- } \\
\text { varying }\end{array}$ & $\begin{array}{l}\text { Country } \\
\text { or Firm }\end{array}$ & $\begin{array}{l}\text { Data } \\
\text { Year }\end{array}$ \\
\hline SECLAW_PUBLIC & $\begin{array}{l}\text { The public enforcement index is the mean of supervisor } \\
\text { characteristics index, investigative powers index, orders index and } \\
\text { criminal index. Following La Porta (2004), measures of public } \\
\text { enforcement are at best modestly associated with market } \\
\text { development. Source: LaPorta et al. (2004). }\end{array}$ & Both & No & Country & 2000 \\
\hline SECLAW & Sum of SECLAW_PUBLIC and SECLAW_PRIVATE & & & & \\
\hline VOICE_ACCT & $\begin{array}{l}\text { Voice and Accountability measures the extent to which country's } \\
\text { citizens are able to participate in selecting their government, as well } \\
\text { as freedom of expression, freedom of association, and a free media. } \\
\text { Source: Kauffman et al. (2009) and World Governance Indicators } \\
\text { Data (World Bank). }\end{array}$ & Both & Annual & Country & $\begin{array}{l}1997 \\
2007\end{array}$ \\
\hline WDI_GOV_AVG & $\begin{array}{l}\text { Country average of the } 6 \text { governance variables CONTROL_CORR, } \\
\text { GOVT_EFFECT, RULE_LAW_WGI, POLITICAL_STAB, } \\
\text { REG_QUALITY, and VOICE_ACCT. Source: Kauffman et al. } \\
\text { (2009) and World Governance Indicators Data (World Bank }\end{array}$ & Both & Annual & Country & $\begin{array}{l}1997 \\
2007\end{array}$ \\
\hline
\end{tabular}


Table I

Summary Statistics

This table reports summary statistics for the full sample of 37,414 takeover deals, collected from the Securities Data Company's (SDC) Global Mergers and Acquisition database by announcement year [Panel A], main industry classification based on Kahle and Walking (1996) [Panel B], and acquirer nation [Panel C].

Panel A: Sample Distribution by Year

\begin{tabular}{|c|c|c|c|c|c|c|}
\hline & Domestic & & Cross Bor & & Combine & \\
\hline Announcment Year & $\mathrm{N}$ & $\begin{array}{c}\% \text { of Sub- } \\
\text { sample } \\
\end{array}$ & $\mathrm{N}$ & $\begin{array}{c}\% \text { of Sub- } \\
\text { sample }\end{array}$ & $\mathrm{N}$ & $\begin{array}{c}\% \text { of Sub- } \\
\text { sample }\end{array}$ \\
\hline 1990 & 554 & $1.89 \%$ & 221 & $2.73 \%$ & 775 & $2.07 \%$ \\
\hline 1991 & 603 & $2.06 \%$ & 153 & $1.89 \%$ & 756 & $2.02 \%$ \\
\hline 1992 & 796 & $2.71 \%$ & 156 & $1.93 \%$ & 952 & $2.54 \%$ \\
\hline 1993 & 1058 & $3.61 \%$ & 174 & $2.15 \%$ & 1232 & $3.29 \%$ \\
\hline 1994 & 1367 & $4.66 \%$ & 266 & $3.29 \%$ & 1633 & $4.36 \%$ \\
\hline 1995 & 1420 & $4.84 \%$ & 299 & $3.70 \%$ & 1719 & $4.59 \%$ \\
\hline 1996 & 1825 & $6.22 \%$ & 401 & $4.96 \%$ & 2226 & $5.95 \%$ \\
\hline 1997 & 2397 & $8.17 \%$ & 503 & $6.22 \%$ & 2900 & $7.75 \%$ \\
\hline 1998 & 2542 & $8.67 \%$ & 632 & $7.81 \%$ & 3174 & $8.48 \%$ \\
\hline 1999 & 2309 & $7.87 \%$ & 657 & $8.12 \%$ & 2966 & $7.93 \%$ \\
\hline 2000 & 2292 & $7.82 \%$ & 798 & $9.86 \%$ & 3090 & $8.26 \%$ \\
\hline 2001 & 1690 & $5.76 \%$ & 585 & $7.23 \%$ & 2275 & $6.08 \%$ \\
\hline 2002 & 1570 & $5.35 \%$ & 433 & $5.35 \%$ & 2003 & $5.35 \%$ \\
\hline 2003 & 1542 & $5.26 \%$ & 397 & $4.91 \%$ & 1939 & $5.18 \%$ \\
\hline 2004 & 1850 & $6.31 \%$ & 536 & $6.63 \%$ & 2386 & $6.38 \%$ \\
\hline 2005 & 1993 & $6.80 \%$ & 626 & $7.74 \%$ & 2619 & $7.00 \%$ \\
\hline 2006 & 2000 & $6.82 \%$ & 655 & $8.10 \%$ & 2655 & $7.10 \%$ \\
\hline 2007 & 1516 & $5.17 \%$ & 598 & $7.39 \%$ & 2114 & $5.65 \%$ \\
\hline Total & 29324 & $100.00 \%$ & 8090 & $100.00 \%$ & 37414 & $100.00 \%$ \\
\hline
\end{tabular}

Panel B: Sample Distribution per Industry

\begin{tabular}{|c|c|c|c|c|c|c|}
\hline & Domestic & & Cross Bor & & Combined & \\
\hline Industry & $\mathrm{N}$ & $\begin{array}{c}\% \text { of Sub- } \\
\text { sample }\end{array}$ & $\mathrm{N}$ & $\begin{array}{c}\% \text { of Sub- } \\
\text { sample }\end{array}$ & $\mathrm{N}$ & $\begin{array}{c}\% \text { of Sub- } \\
\text { sample }\end{array}$ \\
\hline AGRICULTURE & 166 & $0.57 \%$ & 32 & $0.40 \%$ & 198 & $0.53 \%$ \\
\hline MINING & 1837 & $6.27 \%$ & 431 & $5.33 \%$ & 2268 & $6.06 \%$ \\
\hline CONSTRUCTION & 520 & $1.77 \%$ & 86 & $1.06 \%$ & 606 & $1.62 \%$ \\
\hline MANUFACTURING & 8161 & $27.83 \%$ & 3739 & $46.23 \%$ & 11900 & $31.81 \%$ \\
\hline TRANSPORTATION, ETC & 2438 & $8.31 \%$ & 528 & $6.53 \%$ & 2966 & $7.93 \%$ \\
\hline WHOLESALE TRADE & 1174 & $4.00 \%$ & 300 & $3.71 \%$ & 1474 & $3.94 \%$ \\
\hline RETAIL TRADE & 1326 & $4.52 \%$ & 159 & $1.97 \%$ & 1485 & $3.97 \%$ \\
\hline FINANCIALS & 6739 & $22.98 \%$ & 829 & $10.25 \%$ & 7568 & $20.23 \%$ \\
\hline SERVICES & 6929 & $23.63 \%$ & 1979 & $24.47 \%$ & 8908 & $23.81 \%$ \\
\hline GOVERNMENT, REGULATED & 31 & $0.11 \%$ & 4 & $0.05 \%$ & 35 & $0.09 \%$ \\
\hline Total & 29321 & $100.00 \%$ & 8087 & $100.00 \%$ & 37408 & $100.00 \%$ \\
\hline
\end{tabular}


Table I - Continued

\begin{tabular}{|c|c|c|c|c|c|c|}
\hline \multicolumn{7}{|c|}{ Panel C: Sample Distribution per Acquirer Nation } \\
\hline & Domestic & & Cross Bo & der & Combined & \\
\hline Acquiror nation & $\mathrm{N}$ & $\begin{array}{c}\text { \% of Sub- } \\
\text { sample }\end{array}$ & $\mathrm{N}$ & $\begin{array}{c}\% \text { of Sub- } \\
\text { sample }\end{array}$ & $\mathrm{N}$ & $\begin{array}{c}\text { \% of Sub- } \\
\text { sample }\end{array}$ \\
\hline Argentina & 28 & $0.10 \%$ & 1 & $0.01 \%$ & 29 & $0.08 \%$ \\
\hline Australia & 1,537 & $5.24 \%$ & 393 & $4.86 \%$ & 1,930 & $5.16 \%$ \\
\hline Austria & 7 & $0.02 \%$ & 43 & $0.53 \%$ & 50 & $0.13 \%$ \\
\hline Bahamas & 0 & $0.00 \%$ & 5 & $0.06 \%$ & 5 & $0.01 \%$ \\
\hline Belgium & 32 & $0.11 \%$ & 65 & $0.80 \%$ & 97 & $0.26 \%$ \\
\hline Belize & 0 & $0.00 \%$ & 4 & $0.05 \%$ & 4 & $0.01 \%$ \\
\hline Bermuda & 3 & $0.01 \%$ & 29 & $0.36 \%$ & 32 & $0.09 \%$ \\
\hline Brazil & 82 & $0.28 \%$ & 10 & $0.12 \%$ & 92 & $0.25 \%$ \\
\hline British Virgin & 1 & $0.00 \%$ & 0 & $0.00 \%$ & 1 & $0.00 \%$ \\
\hline Canada & 1,522 & $5.19 \%$ & 863 & $10.67 \%$ & 2,385 & $6.37 \%$ \\
\hline Cayman Islands & 0 & $0.00 \%$ & 3 & $0.04 \%$ & 3 & $0.01 \%$ \\
\hline Chile & 28 & $0.10 \%$ & 13 & $0.16 \%$ & 41 & $0.11 \%$ \\
\hline China & 194 & $0.66 \%$ & 15 & $0.19 \%$ & 209 & $0.56 \%$ \\
\hline Colombia & 4 & $0.01 \%$ & 2 & $0.02 \%$ & 6 & $0.02 \%$ \\
\hline Czech Republic & 3 & $0.01 \%$ & 2 & $0.02 \%$ & 5 & $0.01 \%$ \\
\hline Denmark & 56 & $0.19 \%$ & 103 & $1.27 \%$ & 159 & $0.42 \%$ \\
\hline Finland & 130 & $0.44 \%$ & 116 & $1.43 \%$ & 246 & $0.66 \%$ \\
\hline France & 258 & $0.88 \%$ & 263 & $3.25 \%$ & 521 & $1.39 \%$ \\
\hline Germany & 113 & $0.39 \%$ & 215 & $2.66 \%$ & 328 & $0.88 \%$ \\
\hline Gibraltar & 0 & $0.00 \%$ & 1 & $0.01 \%$ & 1 & $0.00 \%$ \\
\hline Greece & 32 & $0.11 \%$ & 15 & $0.19 \%$ & 47 & $0.13 \%$ \\
\hline Guernsey & 0 & $0.00 \%$ & 1 & $0.01 \%$ & 1 & $0.00 \%$ \\
\hline Hong Kong & 223 & $0.76 \%$ & 113 & $1.40 \%$ & 336 & $0.90 \%$ \\
\hline Hungary & 3 & $0.01 \%$ & 9 & $0.11 \%$ & 12 & $0.03 \%$ \\
\hline Iceland & 1 & $0.00 \%$ & 1 & $0.01 \%$ & 2 & $0.01 \%$ \\
\hline India & 83 & $0.28 \%$ & 84 & $1.04 \%$ & 167 & $0.45 \%$ \\
\hline Indonesia & 3 & $0.01 \%$ & 1 & $0.01 \%$ & 4 & $0.01 \%$ \\
\hline Ireland-Rep & 67 & $0.23 \%$ & 222 & $2.74 \%$ & 289 & $0.77 \%$ \\
\hline Isle of Man & 0 & $0.00 \%$ & 7 & $0.09 \%$ & 7 & $0.02 \%$ \\
\hline Israel & 34 & $0.12 \%$ & 102 & $1.26 \%$ & 136 & $0.36 \%$ \\
\hline Italy & 224 & $0.76 \%$ & 112 & $1.38 \%$ & 336 & $0.90 \%$ \\
\hline Japan & 1,111 & $3.79 \%$ & 140 & $1.73 \%$ & 1,251 & $3.34 \%$ \\
\hline Jersey & 1 & $0.00 \%$ & 5 & $0.06 \%$ & 6 & $0.02 \%$ \\
\hline Liechtenstein & 0 & $0.00 \%$ & 1 & $0.01 \%$ & 1 & $0.00 \%$ \\
\hline Luxembourg & 0 & $0.00 \%$ & 8 & $0.10 \%$ & 8 & $0.02 \%$ \\
\hline Malaysia & 429 & $1.46 \%$ & 82 & $1.01 \%$ & 511 & $1.37 \%$ \\
\hline Malta & 1 & $0.00 \%$ & 0 & $0.00 \%$ & 1 & $0.00 \%$ \\
\hline Mexico & 39 & $0.13 \%$ & 23 & $0.28 \%$ & 62 & $0.17 \%$ \\
\hline Neth Antilles & 0 & $0.00 \%$ & 3 & $0.04 \%$ & 3 & $0.01 \%$ \\
\hline Netherlands & 73 & $0.25 \%$ & 198 & $2.45 \%$ & 271 & $0.72 \%$ \\
\hline New Zealand & 76 & $0.26 \%$ & 36 & $0.44 \%$ & 112 & $0.30 \%$ \\
\hline Norway & 123 & $0.42 \%$ & 114 & $1.41 \%$ & 237 & $0.63 \%$ \\
\hline Peru & 6 & $0.02 \%$ & 0 & $0.00 \%$ & 6 & $0.02 \%$ \\
\hline Philippines & 52 & $0.18 \%$ & 9 & $0.11 \%$ & 61 & $0.16 \%$ \\
\hline Poland & 21 & $0.07 \%$ & 2 & $0.02 \%$ & 23 & $0.06 \%$ \\
\hline Portugal & 30 & $0.10 \%$ & 19 & $0.23 \%$ & 49 & $0.13 \%$ \\
\hline Puerto Rico & 3 & $0.01 \%$ & 7 & $0.09 \%$ & 10 & $0.03 \%$ \\
\hline Russian Fed & 1 & $0.00 \%$ & 0 & $0.00 \%$ & 1 & $0.00 \%$ \\
\hline Singapore & 205 & $0.70 \%$ & 167 & $2.06 \%$ & 372 & $0.99 \%$ \\
\hline South Africa & 265 & $0.90 \%$ & 71 & $0.88 \%$ & 336 & $0.90 \%$ \\
\hline South Korea & 105 & $0.36 \%$ & 34 & $0.42 \%$ & 139 & $0.37 \%$ \\
\hline Spain & 150 & $0.51 \%$ & 99 & $1.22 \%$ & 249 & $0.67 \%$ \\
\hline Sri Lanka & 3 & $0.01 \%$ & 0 & $0.00 \%$ & 3 & $0.01 \%$ \\
\hline Sweden & 238 & $0.81 \%$ & 257 & $3.18 \%$ & 495 & $1.32 \%$ \\
\hline Switzerland & 35 & $0.12 \%$ & 115 & $1.42 \%$ & 150 & $0.40 \%$ \\
\hline Taiwan & 49 & $0.17 \%$ & 29 & $0.36 \%$ & 78 & $0.21 \%$ \\
\hline Thailand & 51 & $0.17 \%$ & 10 & $0.12 \%$ & 61 & $0.16 \%$ \\
\hline Turkey & 9 & $0.03 \%$ & 1 & $0.01 \%$ & 10 & $0.03 \%$ \\
\hline Ukraine & 0 & $0.00 \%$ & 8 & $0.10 \%$ & 8 & $0.02 \%$ \\
\hline United Kingdom & 5,241 & $17.87 \%$ & 1,955 & $24.17 \%$ & 7,196 & $19.23 \%$ \\
\hline United States & 16,333 & $55.70 \%$ & 1,884 & $23.29 \%$ & 18,217 & $48.69 \%$ \\
\hline Venezuela & 6 & $0.02 \%$ & 0 & $0.00 \%$ & 6 & $0.02 \%$ \\
\hline Total & 29,324 & $100.00 \%$ & 8,090 & $100.00 \%$ & 37,414 & $100.00 \%$ \\
\hline
\end{tabular}


Table II

\section{Cumulative Abnormal Announcement Returns}

This table provides mean cumulative abnormal returns (CAR) measured from two days prior to two days after the acquisition announcement for the sample of domestic [A] and cross-border [B] deals. CAR is calculated using the market model, where the parameters are estimated over the period starting 205 days to 6 days prior to the announcement using the world index from Datastream as the regressor in the market model. All event returns are winsorized at the $.5 \%$ and $99.5 \%$ level. The number of observations $[\mathrm{N}]$ and CAR are reported for the full sample and the following subsamples: Public targets paid for with cash, public targets paid for with stock, subsidiary targets paid for with cash, private targets paid for with cash, and private targets paid for with stock. The mean difference in CAR between domestic and cross-border deals is reported with its $p$-value, where * indicates significance at the ten-percent level.

\begin{tabular}{|c|c|c|c|c|c|c|}
\hline & \multicolumn{2}{|c|}{ All } & \multicolumn{2}{|c|}{\begin{tabular}{l|l} 
Public & Cash
\end{tabular}} & \multicolumn{2}{|c|}{\begin{tabular}{l|l} 
Public & Stock \\
\end{tabular}} \\
\hline & & Mean & & Mean & & Mean \\
\hline & & Acquirer & & Acquirer & & Acquirer \\
\hline & $\mathrm{N}$ & CAR & $\mathrm{N}$ & CAR & $\mathrm{N}$ & CAR \\
\hline Domestic [A] & 29,324 & $1.42 \%$ & 1,524 & $0.53 \%$ & 2,190 & $-1.18 \%$ \\
\hline Cross Border [B] & 8,090 & $1.50 \%$ & 752 & $1.08 \%$ & 186 & $-2.02 \%$ \\
\hline Total & 37,414 & $1.44 \%$ & 2,276 & $0.71 \%$ & 2,376 & $-1.24 \%$ \\
\hline$[\mathrm{A}]-[\mathrm{B}]$ & & $-0.08 \%$ & & $-0.56 \% *$ & & $0.85 \%$ \\
\hline \multirow[t]{5}{*}{$p$-value } & & 0.480 & & 0.085 & & 0.261 \\
\hline & Subsidi & \begin{tabular}{l|l} 
& Cash \\
\end{tabular} & Private & Cash & Private & Stock \\
\hline & & Mean & & Mean & & Mean \\
\hline & & Acquirer & & Acquirer & & Acquirer \\
\hline & $\mathrm{N}$ & CAR & $\mathrm{N}$ & CAR & $\mathrm{N}$ & CAR \\
\hline Domestic [A] & 5,834 & $1.66 \%$ & 7,306 & $1.24 \%$ & 2,831 & $2.80 \%$ \\
\hline Cross Border [B] & 1,715 & $1.71 \%$ & 2,661 & $1.39 \%$ & 379 & $2.59 \%$ \\
\hline Total & 7,549 & $1.67 \%$ & 9,967 & $1.28 \%$ & 3,210 & $2.77 \%$ \\
\hline$[\mathrm{A}]-[\mathrm{B}]$ & & $-0.06 \%$ & & $-0.14 \%$ & & $0.21 \%$ \\
\hline$p$-value & & 0.783 & & 0.435 & & 0.781 \\
\hline
\end{tabular}




\section{Table III}

Single Country-Characteristic Regression Analysis

This table reports for each country characteristic listed and defined in the Appendix, the regression coefficient on the country characteristic for the acquirer's country and for the target's country, the p-value for the coefficient [in brackets], the number of observations [N], and the adjusted R-squared [AR2] of an ordinary least squares regression. Each regression includes besides one country characteristic at a time, controls for calendar year and the main industry classifications from Kahle and Walkling (1996) of the acquirer. Regression residuals are clustered by country. Statistical significance of the country characteristic regression coefficient is denoted with $* * *, * *$, or $*$ for $p$-values less than one percent, five percent, and ten-percent respectively. 
Table III - Continued

\begin{tabular}{|c|c|c|c|c|c|c|c|}
\hline & & All Deals & $\begin{array}{c}\text { Public } \\
\text { Target \& } \\
\text { Cash }\end{array}$ & $\begin{array}{l}\text { Public } \\
\text { Target \& } \\
\text { Stock }\end{array}$ & $\begin{array}{l}\text { Subsidiary } \\
\text { Target \& } \\
\text { Cash }\end{array}$ & $\begin{array}{c}\text { Private } \\
\text { Target \& } \\
\text { Cash }\end{array}$ & $\begin{array}{c}\text { Private } \\
\text { Target \& } \\
\text { Stock }\end{array}$ \\
\hline & & 1 & 2 & 3 & 4 & 5 & 6 \\
\hline \multirow[t]{6}{*}{ ANTI_SD } & Acquirer & -0.0027 & $0.0209 *$ & $-0.0621^{*}$ & -0.0072 & -0.0030 & -0.0050 \\
\hline & & {$[0.571]$} & [0.073] & {$[0.075]$} & {$[0.290]$} & [0.609] & [0.889] \\
\hline & & -0.0044 & $-0.0240 * *$ & 0.0636 & -0.0091 & $0.0110 * *$ & $-0.0451 * * *$ \\
\hline & Target & {$[0.155]$} & {$[0.031]$} & [0.113] & [0.143] & {$[0.024]$} & {$[0.006]$} \\
\hline & & $\mathrm{N}=7796$ & $\mathrm{~N}=714$ & $\mathrm{~N}=177$ & $\mathrm{~N}=1668$ & $\mathrm{~N}=2561$ & $\mathrm{~N}=357$ \\
\hline & & AR2 $=0.004$ & AR2 $=0.004$ & $\mathrm{AR} 2=-0.047$ & $\mathrm{AR} 2=0.004$ & $\mathrm{AR} 2=0.006$ & $\mathrm{AR} 2=0.033$ \\
\hline \multirow[t]{6}{*}{ ANTI_DIR } & Acquirer & -0.0013 & 0.0037 & $-0.0120^{*}$ & -0.0001 & 0.0002 & -0.0017 \\
\hline & & [0.258] & {$[0.220]$} & [0.099] & {$[0.977]$} & {$[0.930]$} & {$[0.780]$} \\
\hline & & $-0.0027 * *$ & -0.0044 & 0.0077 & -0.0026 & 0.0015 & $-0.0269 * *$ \\
\hline & Target & {$[0.029]$} & {$[0.111]$} & {$[0.453]$} & [0.103] & {$[0.134]$} & {$[0.023]$} \\
\hline & & $\mathrm{N}=7796$ & $\mathrm{~N}=714$ & $\mathrm{~N}=177$ & $\mathrm{~N}=1668$ & $\mathrm{~N}=2561$ & $\mathrm{~N}=357$ \\
\hline & & AR2 $=0.006$ & $\mathrm{AR} 2=0.007$ & AR2 $=0.028$ & $\mathrm{AR} 2=0.007$ & $\mathrm{AR} 2=0.006$ & $\mathrm{AR} 2=0.046$ \\
\hline \multirow[t]{6}{*}{ SHARE_PROTECT } & Acquirer & 0.0005 & 0.0031 & -0.0104 & -0.0008 & 0.0008 & 0.0035 \\
\hline & & {$[0.733]$} & {$[0.224]$} & [0.182] & {$[0.648]$} & {$[0.648]$} & {$[0.714]$} \\
\hline & & -0.0001 & -0.0022 & 0.0041 & -0.0003 & 0.0014 & 0.0044 \\
\hline & Target & {$[0.865]$} & [0.332] & [0.382] & {$[0.755]$} & [0.189] & [0.429] \\
\hline & & $\mathrm{N}=7508$ & $\mathrm{~N}=695$ & $\mathrm{~N}=174$ & $\mathrm{~N}=1628$ & $\mathrm{~N}=2432$ & $\mathrm{~N}=345$ \\
\hline & & $\mathrm{AR} 2=0.006$ & $\mathrm{AR} 2=0.011$ & $\mathrm{AR} 2=0.027$ & $\mathrm{AR} 2=0.008$ & $\mathrm{AR} 2=0.009$ & $\mathrm{AR} 2=0.008$ \\
\hline \multirow[t]{6}{*}{ CREDITOR_RIGHTS } & Acquirer & -0.0015 & 0.0016 & -0.0049 & -0.0013 & -0.0011 & -0.0085 \\
\hline & & {$[0.172]$} & {$[0.567]$} & [0.199] & {$[0.456]$} & {$[0.438]$} & {$[0.210]$} \\
\hline & & $-0.0022^{* *}$ & -0.0026 & -0.0006 & $-0.0019 *$ & -0.0021 & $-0.0161^{* *}$ \\
\hline & Target & {$[0.016]$} & {$[0.242]$} & [0.938] & {$[0.054]$} & {$[0.195]$} & {$[0.044]$} \\
\hline & & $\mathrm{N}=7838$ & $\mathrm{~N}=715$ & $\mathrm{~N}=176$ & $\mathrm{~N}=1674$ & $N=2583$ & $N=363$ \\
\hline & & $\mathrm{AR} 2=0.005$ & $\mathrm{AR} 2=-0.003$ & $\mathrm{AR} 2=-0.062$ & $\mathrm{AR} 2=0.005$ & $\mathrm{AR} 2=0.006$ & $\mathrm{AR} 2=0.043$ \\
\hline \multirow[t]{6}{*}{ SECLAW_PRIVATE } & Acquirer & 0.0050 & 0.0034 & -0.0432 & 0.0039 & 0.0056 & 0.0288 \\
\hline & & {$[0.599]$} & {$[0.708]$} & {$[0.224]$} & [0.687] & [0.669] & {$[0.560]$} \\
\hline & & 0.0018 & 0.0001 & 0.0051 & 0.0038 & 0.0108 & $0.0574 * *$ \\
\hline & Target & {$[0.692]$} & {$[0.990]$} & {$[0.842]$} & [0.383] & {$[0.182]$} & [0.029] \\
\hline & & $\mathrm{N}=7508$ & $\mathrm{~N}=695$ & $\mathrm{~N}=174$ & $\mathrm{~N}=1628$ & $\mathrm{~N}=2432$ & $\mathrm{~N}=345$ \\
\hline & & $\mathrm{AR} 2=0.003$ & $\mathrm{AR} 2=-0.004$ & $\mathrm{AR} 2=-0.060$ & $\mathrm{AR} 2=0.003$ & $\mathrm{AR} 2=0.007$ & $\mathrm{AR} 2=0.021$ \\
\hline \multirow[t]{6}{*}{ SECLAW_PUBLIC } & Acquirer & 0.0065 & 0.0088 & -0.0485 & 0.0002 & 0.0100 & -0.0025 \\
\hline & & {$[0.331]$} & {$[0.324]$} & {$[0.201]$} & [0.972] & [0.314] & {$[0.945]$} \\
\hline & & 0.0042 & -0.0002 & 0.0344 & 0.0038 & 0.0073 & 0.0597 \\
\hline & Target & {$[0.255]$} & {$[0.982]$} & {$[0.190]$} & {$[0.405]$} & {$[0.163]$} & [0.122] \\
\hline & & $\mathrm{N}=7508$ & $\mathrm{~N}=695$ & $\mathrm{~N}=174$ & $\mathrm{~N}=1628$ & $\mathrm{~N}=2432$ & $\mathrm{~N}=345$ \\
\hline & & AR2 $=0.003$ & AR2 $=-0.003$ & AR2 $=-0.056$ & AR2 $=0.003$ & $\mathrm{AR} 2=0.007$ & $\mathrm{AR} 2=0.020$ \\
\hline
\end{tabular}


Table III - Continued

\begin{tabular}{|c|c|c|c|c|c|c|c|}
\hline & & All Deals & $\begin{array}{c}\text { Public } \\
\text { Target \& } \\
\text { Cash }\end{array}$ & $\begin{array}{c}\text { Public } \\
\text { Target \& } \\
\text { Stock }\end{array}$ & $\begin{array}{c}\text { Subsidiary } \\
\text { Target \& } \\
\text { Cash }\end{array}$ & $\begin{array}{c}\text { Private } \\
\text { Target \& } \\
\text { Cash }\end{array}$ & $\begin{array}{c}\text { Private } \\
\text { Target \& } \\
\text { Stock }\end{array}$ \\
\hline & & 1 & 2 & 3 & 4 & 5 & 6 \\
\hline \multirow[t]{6}{*}{$\overline{\text { ACCOUNT }}$} & Acquirer & 0.0002 & $0.0015^{* * *}$ & 0.0001 & -0.0001 & 0.0002 & -0.0011 \\
\hline & & {$[0.342]$} & {$[0.000]$} & [0.944] & {$[0.664]$} & {$[0.460]$} & {$[0.533]$} \\
\hline & & $-0.0002 * *$ & $-0.0007 * * *$ & 0.0020 & -0.0004 & 0.0001 & $-0.0017 *$ \\
\hline & Target & {$[0.023]$} & {$[0.007]$} & {$[0.185]$} & {$[0.112]$} & {$[0.634]$} & {$[0.057]$} \\
\hline & & $\mathrm{N}=7176$ & $N=675$ & $N=166$ & $\mathrm{~N}=1567$ & $\mathrm{~N}=2322$ & $\mathrm{~N}=336$ \\
\hline & & $\mathrm{AR} 2=0.004$ & $\mathrm{AR} 2=0.020$ & $\mathrm{AR} 2=-0.062$ & $\mathrm{AR} 2=0.006$ & $\mathrm{AR} 2=0.005$ & $\mathrm{AR} 2=0.015$ \\
\hline \multirow[t]{6}{*}{ CONTROL_CORR } & Acquirer & $0.0048^{*}$ & $0.0118^{* * *}$ & -0.0011 & 0.0012 & 0.0032 & 0.0175 \\
\hline & & {$[0.053]$} & {$[0.003]$} & {$[0.960]$} & {$[0.776]$} & {$[0.291]$} & {$[0.372]$} \\
\hline & & $-0.0035^{* * *}$ & $-0.0063^{* *}$ & -0.0164 & -0.0040 & 0.0002 & -0.0154 \\
\hline & Target & {$[0.002]$} & {$[0.034]$} & {$[0.496]$} & {$[0.175]$} & {$[0.894]$} & {$[0.184]$} \\
\hline & & $\mathrm{N}=7991$ & $\mathrm{~N}=742$ & $\mathrm{~N}=182$ & $\mathrm{~N}=1699$ & $\mathrm{~N}=2629$ & $\mathrm{~N}=372$ \\
\hline & & $\mathrm{AR} 2=0.004$ & $\mathrm{AR} 2=0.007$ & $\mathrm{AR} 2=-0.056$ & $\mathrm{AR} 2=0.005$ & $\mathrm{AR} 2=0.005$ & $\mathrm{AR} 2=0.021$ \\
\hline \multirow[t]{6}{*}{ GOVT_EFF } & Acquirer & $0.0064^{* *}$ & $0.0193^{* * *}$ & -0.0213 & -0.0018 & 0.0061 & 0.0261 \\
\hline & & {$[0.025]$} & {$[0.001]$} & {$[0.426]$} & {$[0.718]$} & {$[0.142]$} & [0.339] \\
\hline & & $-0.0037 * * *$ & $-0.0074 * *$ & -0.0126 & -0.0031 & -0.0001 & -0.0099 \\
\hline & Target & {$[0.005]$} & {$[0.024]$} & {$[0.604]$} & {$[0.418]$} & {$[0.977]$} & {$[0.530]$} \\
\hline & & $\mathrm{N}=7991$ & $\mathrm{~N}=742$ & $\mathrm{~N}=182$ & $\mathrm{~N}=1699$ & $\mathrm{~N}=2629$ & $\mathrm{~N}=372$ \\
\hline & & $\mathrm{AR} 2=0.004$ & $\mathrm{AR} 2=0.013$ & $\mathrm{AR} 2=-0.055$ & $\mathrm{AR} 2=0.004$ & $\mathrm{AR} 2=0.005$ & $\mathrm{AR} 2=0.018$ \\
\hline \multirow[t]{6}{*}{ POL_STAB } & Acquirer & 0.0036 & $0.0096 * *$ & 0.0031 & 0.0013 & 0.0044 & 0.0038 \\
\hline & & {$[0.216]$} & {$[0.025]$} & [0.879] & {$[0.825]$} & {$[0.208]$} & {$[0.857]$} \\
\hline & & $-0.0048 * *$ & -0.0040 & $0.0443^{* *}$ & -0.0055 & -0.0007 & $-0.0320 *$ \\
\hline & Target & {$[0.041]$} & {$[0.275]$} & {$[0.042]$} & {$[0.351]$} & {$[0.682]$} & {$[0.064]$} \\
\hline & & $\mathrm{N}=7992$ & $\mathrm{~N}=742$ & $\mathrm{~N}=182$ & $\mathrm{~N}=1700$ & $\mathrm{~N}=2629$ & $\mathrm{~N}=372$ \\
\hline & & $\mathrm{AR} 2=0.004$ & $\mathrm{AR} 2=0.001$ & $\mathrm{AR} 2=-0.039$ & $\mathrm{AR} 2=0.005$ & $\mathrm{AR} 2=0.005$ & $\mathrm{AR} 2=0.026$ \\
\hline \multirow[t]{6}{*}{ REG_QUALITY } & Acquirer & 0.0011 & $0.0169 * * *$ & $-0.0567 *$ & -0.0053 & -0.0000 & 0.0088 \\
\hline & & [0.597] & [0.008] & {$[0.051]$} & {$[0.314]$} & [0.993] & [0.709] \\
\hline & & $-0.0044 * * *$ & $-0.0089 * *$ & -0.0192 & -0.0019 & 0.0014 & -0.0165 \\
\hline & Target & {$[0.010]$} & {$[0.044]$} & {$[0.618]$} & {$[0.650]$} & {$[0.592]$} & {$[0.444]$} \\
\hline & & $\mathrm{N}=7992$ & $\mathrm{~N}=742$ & $\mathrm{~N}=182$ & $\mathrm{~N}=1700$ & $\mathrm{~N}=2629$ & $\mathrm{~N}=372$ \\
\hline & & $\mathrm{AR} 2=0.004$ & AR2 $=0.007$ & $\mathrm{AR} 2=-0.044$ & $\mathrm{AR} 2=0.004$ & $\mathrm{AR} 2=0.004$ & $\mathrm{AR} 2=0.017$ \\
\hline \multirow[t]{6}{*}{ RULELAW_WGI } & Acquirer & $0.0050^{*}$ & $0.0150 * * *$ & -0.0055 & -0.0009 & 0.0028 & 0.0257 \\
\hline & & {$[0.085]$} & {$[0.001]$} & [0.773] & {$[0.878]$} & {$[0.482]$} & [0.328] \\
\hline & & $-0.0037 * *$ & -0.0058 & -0.0206 & -0.0019 & 0.0000 & -0.0179 \\
\hline & Target & {$[0.011]$} & [0.102] & [0.589] & {$[0.576]$} & [0.988] & {$[0.272]$} \\
\hline & & $\mathrm{N}=7992$ & $\mathrm{~N}=742$ & $\mathrm{~N}=182$ & $\mathrm{~N}=1700$ & $\mathrm{~N}=2629$ & $\mathrm{~N}=372$ \\
\hline & & AR2 $=0.004$ & AR2 $=0.006$ & $\mathrm{AR} 2=-0.056$ & $\mathrm{AR} 2=0.004$ & AR2 $=0.005$ & $\mathrm{AR} 2=0.021$ \\
\hline
\end{tabular}


Table III - Continued

\begin{tabular}{|c|c|c|c|c|c|c|c|}
\hline & & All Deals & $\begin{array}{c}\text { Public } \\
\text { Target \& } \\
\text { Cash }\end{array}$ & $\begin{array}{c}\text { Public } \\
\text { Target \& } \\
\text { Stock }\end{array}$ & $\begin{array}{c}\text { Subsidiary } \\
\text { Target \& } \\
\text { Cash }\end{array}$ & $\begin{array}{c}\text { Private } \\
\text { Target \& } \\
\text { Cash }\end{array}$ & $\begin{array}{c}\text { Private } \\
\text { Target \& } \\
\text { Stock }\end{array}$ \\
\hline & & 1 & 2 & 3 & 4 & 5 & 6 \\
\hline \multirow[t]{6}{*}{ VOICE_ACCT } & Acquirer & $0.0064^{*}$ & $0.0117^{*}$ & 0.0154 & -0.0006 & 0.0024 & $0.0408^{*}$ \\
\hline & & {$[0.088]$} & {$[0.086]$} & [0.694] & [0.907] & {$[0.590]$} & {$[0.064]$} \\
\hline & & $-0.0046^{* *}$ & -0.0080 & -0.0146 & 0.0010 & -0.0004 & -0.0162 \\
\hline & Target & [0.019] & [0.165] & [0.588] & {$[0.773]$} & [0.839] & {$[0.220]$} \\
\hline & & $\mathrm{N}=7986$ & $\mathrm{~N}=742$ & $\mathrm{~N}=182$ & $N=1699$ & $\mathrm{~N}=2625$ & $\mathrm{~N}=372$ \\
\hline & & $\mathrm{AR} 2=0.004$ & $\mathrm{AR} 2=0.002$ & $\mathrm{AR} 2=-0.056$ & $\mathrm{AR} 2=0.003$ & $\mathrm{AR} 2=0.005$ & $\mathrm{AR} 2=0.027$ \\
\hline \multirow[t]{6}{*}{ WDI_GOV_AVG } & Acquirer & $0.0061^{*}$ & $0.0178 * * *$ & -0.0108 & -0.0007 & 0.0043 & 0.0295 \\
\hline & & {$[0.077]$} & {$[0.001]$} & [0.695] & {$[0.908]$} & {$[0.326]$} & {$[0.360]$} \\
\hline & & $-0.0047 * * *$ & $-0.0083^{* *}$ & -0.0043 & -0.0029 & -0.0000 & -0.0205 \\
\hline & Target & {$[0.006]$} & {$[0.044]$} & [0.899] & [0.489] & [0.998] & {$[0.233]$} \\
\hline & & $\mathrm{N}=7992$ & $\mathrm{~N}=742$ & $\mathrm{~N}=182$ & $\mathrm{~N}=1700$ & $\mathrm{~N}=2629$ & $\mathrm{~N}=372$ \\
\hline & & $\mathrm{AR} 2=0.004$ & $\mathrm{AR} 2=0.008$ & $\mathrm{AR} 2=-0.058$ & $\mathrm{AR} 2=0.004$ & $\mathrm{AR} 2=0.005$ & $\mathrm{AR} 2=0.022$ \\
\hline \multirow[t]{6}{*}{ IT_LAW } & Acquirer & 0.0044 & -0.0045 & $-0.0640 * * *$ & 0.0128 & $-0.0356 * * *$ & $0.0681 * *$ \\
\hline & & [0.469] & {$[0.690]$} & {$[0.001]$} & [0.286] & {$[0.000]$} & {$[0.012]$} \\
\hline & & -0.0063 & -0.0258 & 0.0081 & -0.0028 & -0.0110 & 0.0393 \\
\hline & Target & [0.282] & [0.139] & [0.469] & [0.692] & [0.105] & [0.314] \\
\hline & & $\mathrm{N}=7866$ & $\mathrm{~N}=727$ & $\mathrm{~N}=180$ & $\mathrm{~N}=1680$ & $\mathrm{~N}=2582$ & $\mathrm{~N}=364$ \\
\hline & & $\mathrm{AR} 2=0.003$ & $\mathrm{AR} 2=-0.000$ & $\mathrm{AR} 2=-0.062$ & $\mathrm{AR} 2=0.004$ & $\mathrm{AR} 2=0.008$ & $\mathrm{AR} 2=0.026$ \\
\hline \multirow[t]{6}{*}{ IT_ENF } & Acquirer & $0.0059 * *$ & 0.0030 & 0.0100 & 0.0066 & 0.0020 & 0.0159 \\
\hline & & {$[0.040]$} & {$[0.617]$} & [0.558] & [0.194] & [0.684] & [0.543] \\
\hline & & $-0.0056^{* * *} *$ & -0.0112 & -0.0323 & -0.0034 & -0.0002 & -0.0357 \\
\hline & Target & [0.003] & [0.163] & {$[0.216]$} & {$[0.531]$} & [0.958] & [0.166] \\
\hline & & $\mathrm{N}=7866$ & $\mathrm{~N}=727$ & $\mathrm{~N}=180$ & $\mathrm{~N}=1680$ & $\mathrm{~N}=2582$ & $\mathrm{~N}=364$ \\
\hline & & $\mathrm{AR} 2=0.004$ & $\mathrm{AR} 2=-0.000$ & $\mathrm{AR} 2=-0.057$ & $\mathrm{AR} 2=0.005$ & $\mathrm{AR} 2=0.006$ & $\mathrm{AR} 2=0.030$ \\
\hline \multirow[t]{6}{*}{ GDP_PCAP } & Acquirer & -0.0000 & 0.0002 & 0.0006 & -0.0003 & -0.0001 & -0.0006 \\
\hline & & [0.673] & [0.282] & [0.303] & [0.153] & [0.374] & [0.590] \\
\hline & & 0.0000 & 0.0001 & -0.0003 & 0.0001 & 0.0002 & 0.0002 \\
\hline & Target & {$[0.914]$} & {$[0.824]$} & [0.682] & {$[0.735]$} & [0.117] & {$[0.857]$} \\
\hline & & $\mathrm{N}=7939$ & $\mathrm{~N}=729$ & $\mathrm{~N}=182$ & $\mathrm{~N}=1688$ & $\mathrm{~N}=2610$ & $\mathrm{~N}=373$ \\
\hline & & $\mathrm{AR} 2=0.003$ & $\mathrm{AR} 2=-0.001$ & $\mathrm{AR} 2=-0.063$ & $\mathrm{AR} 2=0.005$ & $\mathrm{AR} 2=0.007$ & $\mathrm{AR} 2=0.014$ \\
\hline \multirow[t]{6}{*}{ MKTCAP_GDP } & Acquirer & 0.0005 & 0.0076 & -0.0081 & 0.0027 & 0.0008 & $-0.0341 * *$ \\
\hline & & {$[0.787]$} & [0.228] & [0.659] & [0.273] & {$[0.778]$} & {$[0.027]$} \\
\hline & & $-0.0032 * *$ & $-0.0079 *$ & $0.0343^{*}$ & -0.0030 & -0.0001 & -0.0077 \\
\hline & Target & [0.019] & {$[0.054]$} & {$[0.085]$} & {$[0.252]$} & [0.964] & [0.534] \\
\hline & & $\mathrm{N}=7793$ & $\mathrm{~N}=721$ & $\mathrm{~N}=176$ & $\mathrm{~N}=1657$ & $\mathrm{~N}=2564$ & $N=362$ \\
\hline & & $\mathrm{AR} 2=0.004$ & $\mathrm{AR} 2=0.003$ & $\mathrm{AR} 2=-0.048$ & $\mathrm{AR} 2=0.005$ & AR2 $=0.005$ & $\mathrm{AR} 2=0.035$ \\
\hline
\end{tabular}


Table III - Continued

\begin{tabular}{|c|c|c|c|c|c|c|c|}
\hline & & All Deals & $\begin{array}{c}\text { Public } \\
\text { Target \& } \\
\text { Cash }\end{array}$ & $\begin{array}{c}\text { Public } \\
\text { Target \& } \\
\text { Stock }\end{array}$ & $\begin{array}{c}\text { Subsidiary } \\
\text { Target \& } \\
\text { Cash }\end{array}$ & $\begin{array}{c}\text { Private } \\
\text { Target \& } \\
\text { Cash }\end{array}$ & $\begin{array}{c}\text { Private } \\
\text { Target \& } \\
\text { Stock }\end{array}$ \\
\hline & & 1 & 2 & 3 & 4 & 5 & 6 \\
\hline \multirow[t]{6}{*}{ CTRY_TURNOVER } & Acquirer & -0.0025 & 0.0006 & 0.0279* & $-0.0107 * * *$ & -0.0052 & 0.0015 \\
\hline & & [0.308] & {$[0.901]$} & {$[0.059]$} & {$[0.001]$} & {$[0.164]$} & [0.936] \\
\hline & & 0.0011 & 0.0005 & 0.0061 & 0.0026 & 0.0008 & 0.0157 \\
\hline & Target & {$[0.616]$} & [0.917] & {$[0.641]$} & [0.509] & {$[0.837]$} & [0.435] \\
\hline & & $\mathrm{N}=7827$ & $\mathrm{~N}=727$ & $\mathrm{~N}=179$ & $N=1659$ & $\mathrm{~N}=2575$ & $\mathrm{~N}=365$ \\
\hline & & $\mathrm{AR} 2=0.004$ & $\mathrm{AR} 2=-0.001$ & $\mathrm{AR} 2=-0.051$ & $\mathrm{AR} 2=0.009$ & $\mathrm{AR} 2=0.006$ & $\mathrm{AR} 2=0.019$ \\
\hline \multirow[t]{6}{*}{ CTRY_RET_1YR } & Acquirer & 0.0001 & -0.0108 & 0.0426 & 0.0050 & -0.0013 & -0.0025 \\
\hline & & [0.982] & {$[0.572]$} & {$[0.224]$} & [0.619] & {$[0.911]$} & [0.922] \\
\hline & & 0.0070 & 0.0076 & $0.0818 * *$ & 0.0001 & 0.0067 & 0.0307 \\
\hline & Target & {$[0.140]$} & {$[0.591]$} & {$[0.034]$} & [0.995] & {$[0.464]$} & {$[0.538]$} \\
\hline & & $\mathrm{N}=7422$ & $\mathrm{~N}=668$ & $\mathrm{~N}=173$ & $\mathrm{~N}=1597$ & $\mathrm{~N}=2410$ & $\mathrm{~N}=339$ \\
\hline & & $\mathrm{AR} 2=0.004$ & $\mathrm{AR} 2=-0.006$ & $\mathrm{AR} 2=-0.048$ & $\mathrm{AR} 2=0.003$ & $\mathrm{AR} 2=0.005$ & $\mathrm{AR} 2=0.026$ \\
\hline \multirow[t]{6}{*}{ LIB_INT_AVG } & Acquirer & -0.0234 & $0.1462 * * *$ & $0.0752 * *$ & $-0.0797 *$ & -0.0058 & -0.1341 \\
\hline & & {$[0.348]$} & {$[0.000]$} & {$[0.043]$} & {$[0.076]$} & [0.678] & {$[0.268]$} \\
\hline & & -0.0150 & -0.0405 & 6.4232 & -0.0193 & 0.0008 & $0.1339 * * *$ \\
\hline & Target & [0.339] & [0.324] & [0.482] & [0.575] & [0.948] & {$[0.000]$} \\
\hline & & $\mathrm{N}=7275$ & $\mathrm{~N}=660$ & $\mathrm{~N}=174$ & $N=1586$ & $\mathrm{~N}=2343$ & $\mathrm{~N}=330$ \\
\hline & & $\mathrm{AR} 2=0.006$ & $\mathrm{AR} 2=0.014$ & $\mathrm{AR} 2=0.019$ & $\mathrm{AR} 2=0.014$ & $\mathrm{AR} 2=0.011$ & $\mathrm{AR} 2=0.024$ \\
\hline \multirow[t]{4}{*}{ INSIDE_PCT } & Acquirer & $0.0116^{* * *}$ & $0.0256^{* *}$ & $0.1012 * *$ & $0.0133^{*}$ & 0.0056 & -0.0196 \\
\hline & & {$[0.001]$} & {$[0.022]$} & [0.017] & {$[0.066]$} & [0.322] & {$[0.647]$} \\
\hline & & $\mathrm{N}=6398$ & $\mathrm{~N}=628$ & $\mathrm{~N}=138$ & $\mathrm{~N}=1380$ & $\mathrm{~N}=2078$ & $\mathrm{~N}=260$ \\
\hline & & $\mathrm{AR} 2=0.005$ & $\mathrm{AR} 2=0.001$ & $\mathrm{AR} 2=-0.024$ & $\mathrm{AR} 2=0.005$ & $\mathrm{AR} 2=0.002$ & $\mathrm{AR} 2=0.041$ \\
\hline \multirow[t]{6}{*}{ ADR } & Acquirer & $-0.0079 * * *$ & $-0.0106^{* *}$ & -0.0359 & 0.0017 & -0.0056 & $0.0298 * *$ \\
\hline & & {$[0.000]$} & [0.044] & [0.122] & [0.708] & [0.125] & [0.015] \\
\hline & & $0.0084^{* *}$ & 0.0122 & $-0.0269 *$ & $0.0089 * *$ & 0.0000 & 0.0000 \\
\hline & Target & [0.013] & {$[0.226]$} & [0.065] & [0.045] & [.] & {$[]$.} \\
\hline & & $\mathrm{N}=8060$ & $\mathrm{~N}=747$ & $\mathrm{~N}=184$ & $\mathrm{~N}=1709$ & $\mathrm{~N}=2654$ & $\mathrm{~N}=379$ \\
\hline & & AR2 $=0.005$ & AR2 $=0.003$ & AR2 $=-0.038$ & AR2 $=0.006$ & AR2 $=0.005$ & $\mathrm{AR} 2=0.022$ \\
\hline
\end{tabular}




\section{Table IV \\ Multivariate Regression Analysis}

This table presents the regression coefficients for OLS regression models where the dependent variable is the acquirer return and the independent variables are measures for governance, financial development, and economic development (see Appendix for definitions) in Panel A and the same regressions with insider ownership in Panel B. Each regression includes industry indicator variables based on the main industry classifications from Kahle and Walking (1996). Regression residuals are clustered by country. Statistical significance of the regression coefficients is denoted with $* * *, * *$, or $*$ for $p$-values less than one percent, five percent, and ten-percent respectively. 
Table IV - Continued

Panel A

\begin{tabular}{lcccccc}
\hline & & Public & Public & Subsidiary & Private & Private \\
& Target \& & Target \& & Target \& & Target \& & Target \& \\
Cash & Stock & Cash & Cash & Stock \\
VARIABLES & $(1)$ & $(2)$ & $(3)$ & $(4)$ & $(5)$ & $(6)$ \\
\hline WDI_GOV_AVG acquirer & $0.0076^{* *}$ & $0.0196^{* *}$ & 0.0088 & 0.0022 & $0.0128^{* *}$ & 0.0296 \\
& {$[0.038]$} & {$[0.029]$} & {$[0.802]$} & {$[0.724]$} & {$[0.018]$} & {$[0.319]$} \\
WDI_GOV_AVG target & $-0.0096^{* * *}$ & $-0.0141^{* *}$ & 0.0057 & -0.0059 & -0.0016 & $-0.0700^{* * *}$ \\
& {$[0.000]$} & {$[0.047]$} & {$[0.854]$} & {$[0.126]$} & {$[0.587]$} & {$[0.001]$} \\
GDP_PCAP acquirer & -0.0002 & -0.0003 & 0.0012 & -0.0003 & $-0.0006^{* * *}$ & 0.0002 \\
& {$[0.128]$} & {$[0.281]$} & {$[0.343]$} & {$[0.202]$} & {$[0.004]$} & {$[0.810]$} \\
GDP_PCAP target & $0.0004^{* * *}$ & 0.0005 & -0.0011 & $0.0004^{*}$ & $0.0002^{*}$ & $0.0023^{*}$ \\
& {$[0.007]$} & {$[0.323]$} & {$[0.409]$} & {$[0.086]$} & {$[0.051]$} & {$[0.062]$} \\
MKTCAP_GDP acquirer & 0.0005 & 0.0069 & -0.0118 & 0.0040 & 0.0022 & $-0.0369 * *$ \\
& {$[0.797]$} & {$[0.153]$} & {$[0.636]$} & {$[0.167]$} & {$[0.401]$} & {$[0.023]$} \\
MKTCAP_GDP target & $-0.0038^{* *}$ & -0.0066 & $0.0421^{*}$ & -0.0045 & -0.0026 & -0.0057 \\
& {$[0.012]$} & {$[0.179]$} & {$[0.092]$} & {$[0.159]$} & {$[0.176]$} & {$[0.640]$} \\
Observations & 7787 & 718 & 176 & 1656 & 2562 & 362 \\
Adjusted R-squared & 0.008 & 0.016 & 0.019 & 0.009 & 0.008 & 0.044 \\
\hline
\end{tabular}

Panel B

\begin{tabular}{|c|c|c|c|c|c|c|}
\hline VARIABLES & $\begin{array}{l}\text { All } \\
(1) \\
\end{array}$ & $\begin{array}{c}\text { Public } \\
\text { Target \& } \\
\text { Cash } \\
(2) \\
\end{array}$ & $\begin{array}{c}\text { Public } \\
\text { Target \& } \\
\text { Stock } \\
(3) \\
\end{array}$ & $\begin{array}{c}\text { Subsidiary } \\
\text { Target \& } \\
\text { Cash } \\
(4)\end{array}$ & $\begin{array}{c}\text { Private } \\
\text { Target \& } \\
\text { Cash } \\
(5)\end{array}$ & $\begin{array}{c}\text { Private } \\
\text { Target \& } \\
\text { Stock } \\
(6) \\
\end{array}$ \\
\hline WDI_GOV_AVG acquirer & $\begin{array}{c}0.0088^{* *} \\
{[0.011]}\end{array}$ & $\begin{array}{c}0.0198 * * \\
{[0.039]}\end{array}$ & $\begin{array}{l}-0.0211 \\
{[0.516]}\end{array}$ & $\begin{array}{c}0.0011 \\
{[0.885]}\end{array}$ & $\begin{array}{c}0.0155^{* * *} \\
{[0.002]}\end{array}$ & $\begin{array}{c}0.1107^{* *} \\
{[0.042]}\end{array}$ \\
\hline WDI_GOV_AVG target & $\begin{array}{c}-0.0090 * * * \\
{[0.000]}\end{array}$ & $\begin{array}{c}-0.0214^{* *} \\
{[0.020]}\end{array}$ & $\begin{array}{l}0.0301 \\
{[0.428]}\end{array}$ & $\begin{array}{c}-0.0079 * * \\
{[0.032]}\end{array}$ & $\begin{array}{l}-0.0033 \\
{[0.280]}\end{array}$ & $\begin{array}{c}-0.0610^{* *} \\
{[0.019]}\end{array}$ \\
\hline GDP_PCAP acquirer & $\begin{array}{l}-0.0001 \\
{[0.276]}\end{array}$ & $\begin{array}{l}-0.0003 \\
{[0.402]}\end{array}$ & $\begin{array}{l}0.0023 \\
{[0.106]}\end{array}$ & $\begin{array}{l}-0.0001 \\
{[0.836]}\end{array}$ & $\begin{array}{c}-0.0005^{* * *} \\
{[0.001]}\end{array}$ & $\begin{array}{l}0.0001 \\
{[0.946]}\end{array}$ \\
\hline GDP_PCAP target & $\begin{array}{c}0.0004^{* * *} \\
{[0.003]}\end{array}$ & $\begin{array}{l}0.0008 \\
{[0.100]}\end{array}$ & $\begin{array}{l}-0.0002 \\
{[0.920]}\end{array}$ & $\begin{array}{c}0.0005^{* *} \\
{[0.022]}\end{array}$ & $\begin{array}{l}0.0004^{*} \\
{[0.055]}\end{array}$ & $\begin{array}{l}0.0023 \\
{[0.136]}\end{array}$ \\
\hline MKTCAP_GDP acquirer & $\begin{array}{l}0.0028 * \\
{[0.089]}\end{array}$ & $\begin{array}{l}0.0077 \\
{[0.191]}\end{array}$ & $\begin{array}{l}0.0032 \\
{[0.908]}\end{array}$ & $\begin{array}{l}0.0049 * \\
{[0.071]}\end{array}$ & $\begin{array}{c}0.0057 * * \\
{[0.036]}\end{array}$ & $\begin{array}{l}-0.0279 \\
{[0.153]}\end{array}$ \\
\hline MKTCAP_GDP target & $\begin{array}{c}-0.0051^{* *} \\
{[0.010]}\end{array}$ & $\begin{array}{l}-0.0054 \\
{[0.177]}\end{array}$ & $\begin{array}{l}0.0305 \\
{[0.324]}\end{array}$ & $\begin{array}{l}-0.0051 \\
{[0.190]}\end{array}$ & $\begin{array}{c}-0.0053^{* *} \\
{[0.025]}\end{array}$ & $\begin{array}{r}-0.0042 \\
{[0.757]}\end{array}$ \\
\hline INSIDE_PCT & $\begin{array}{c}0.0149 * * * \\
{[0.000]}\end{array}$ & $\begin{array}{c}0.0277^{* *} \\
{[0.048]}\end{array}$ & $\begin{array}{c}0.1230 * * * \\
{[0.000]}\end{array}$ & $\begin{array}{c}0.0157 * * \\
{[0.014]}\end{array}$ & $\begin{array}{l}0.0083 \\
{[0.253]}\end{array}$ & $\begin{array}{l}-0.0182 \\
{[0.701]}\end{array}$ \\
\hline $\begin{array}{l}\text { Observations } \\
\text { Adjusted R-squared }\end{array}$ & $\begin{array}{r}6199 \\
0.010 \\
\end{array}$ & $\begin{array}{c}609 \\
0.019 \\
\end{array}$ & $\begin{array}{c}134 \\
-0.032 \\
\end{array}$ & $\begin{array}{l}1337 \\
0.019 \\
\end{array}$ & $\begin{array}{r}2009 \\
0.006\end{array}$ & $\begin{array}{c}251 \\
0.065 \\
\end{array}$ \\
\hline
\end{tabular}


Table V

Explanatory Power of Indicator Variable Regressions

This table reports the R-squared, $p$-value for an F-test of the joint significance of the indicator variables, and the number of observations $(\mathrm{N})$ in regressions for the whole sample (All) and each sub-sample. Models (1) through (5) exclusively include respectively calendar year, acquirer country, industry, target country, and all indicator variables in one regression. We only include countries and industries with five acquisitions at least.

\begin{tabular}{|c|c|c|c|c|c|}
\hline All & $(1)$ & (2) & (3) & (4) & (5) \\
\hline Indicators & Year & Country (A) & Industry & Country (T) & All \\
\hline R-squared & 0.0050 & 0.0060 & 0.0040 & 0.0190 & 0.0330 \\
\hline Prob $>$ F & 0.0003 & 0.2130 & 0.0003 & 0.0219 & 0.0001 \\
\hline Observations & 8060 & 8060 & 8060 & 8060 & 8060 \\
\hline Public | Cash & $(1)$ & $(2)$ & (3) & (4) & (5) \\
\hline Indicators & Year & Country (A) & Industry & Country $(T)$ & All \\
\hline R-squared & 0.024 & 0.023 & 0.012 & 0.095 & 0.154 \\
\hline Prob $>$ F & 0.4510 & 0.9120 & 0.2570 & 0.2720 & 0.5000 \\
\hline Observations & 721 & 721 & 721 & 721 & 721 \\
\hline Public | Stock & $(1)$ & $(2)$ & (3) & (4) & (5) \\
\hline Indicators & Year & Country (A) & Industry & Country (T) & All \\
\hline R-squared & 0.065 & 0.012 & 0.097 & 0.143 & 0.336 \\
\hline Prob $>$ F & 0.8420 & 0.9740 & 0.0097 & 0.5530 & 0.4400 \\
\hline Observations & 153 & 153 & 153 & 153 & 153 \\
\hline Subsidiary | Cash & (1) & (2) & (3) & (4) & (5) \\
\hline Indicators & Year & Country (A) & Industry & Country (T) & All \\
\hline R-squared & 0.016 & 0.020 & 0.009 & 0.081 & 0.119 \\
\hline Prob $>$ F & 0.0716 & 0.218 & 0.0540 & $<0.0001$ & $<0.0001$ \\
\hline Observations & 1685 & 1685 & 1685 & 1685 & 1685 \\
\hline Private | Cash & (1) & (2) & (3) & (4) & (5) \\
\hline Indicators & Year & Country (A) & Industry & Country (T) & All \\
\hline R-squared & 0.011 & 0.017 & 0.005 & 0.041 & 0.071 \\
\hline Prob $>$ F & 0.0253 & 0.1310 & 0.0948 & 0.0771 & 0.0177 \\
\hline Observations & 2641 & 2641 & 2641 & 2641 & 2641 \\
\hline Private | Stock & (1) & (2) & (3) & (4) & (5) \\
\hline Indicators & Year & Country (A) & Industry & Country (T) & All \\
\hline R-squared & 0.063 & 0.075 & 0.006 & 0.203 & 0.296 \\
\hline Prob $>$ F & 0.1750 & 0.0087 & 0.8220 & 0.0143 & 0.0398 \\
\hline Observations & 350 & 350 & 350 & 350 & 350 \\
\hline
\end{tabular}




\section{Table VI \\ Global Effect Regressions}

This table presents the regression coefficients for OLS regression models where the dependent variable is the acquirer return and the independent variable is the average acquirer return for acquisitions of the same type made in other countries in the same year (GLOBAL_EFFECT). Each regression includes industry indicator variables based on the main industry classifications from Kahle and Walking (1996). Regression residuals are clustered by country. Statistical significance of the regression coefficients is denoted with $* * *, * *$, or * for $p$-values less than one percent, five percent, and ten-percent respectively.

\begin{tabular}{|c|c|c|c|c|c|c|}
\hline VARIABLES & $\begin{array}{l}\text { All } \\
\text { (1) }\end{array}$ & $\begin{array}{c}\text { Public } \\
\text { Targets \& } \\
\text { Cash } \\
(2)\end{array}$ & $\begin{array}{c}\text { Public } \\
\text { Targets \& } \\
\text { Stock } \\
(3)\end{array}$ & $\begin{array}{c}\text { Subsidiary } \\
\text { Targets \& } \\
\text { Cash } \\
(4)\end{array}$ & $\begin{array}{c}\text { Private } \\
\text { Targets \& } \\
\text { Cash } \\
(5)\end{array}$ & $\begin{array}{c}\text { Private } \\
\text { Targets \& } \\
\text { Stock } \\
(6)\end{array}$ \\
\hline GLOBAL_EFFECT & $\begin{array}{c}0.4878^{* *} \\
{[0.028]}\end{array}$ & $\begin{array}{l}-0.4900 \\
{[0.333]}\end{array}$ & $\begin{array}{l}0.4529 \\
{[0.349]}\end{array}$ & $\begin{array}{l}0.4452^{*} \\
{[0.086]}\end{array}$ & $\begin{array}{c}0.5471^{* * *} \\
{[0.008]}\end{array}$ & $\begin{array}{c}0.7130 * * * \\
{[0.000]}\end{array}$ \\
\hline Constant & $\begin{array}{c}0.0101 \\
{[0.181]}\end{array}$ & $\begin{array}{c}0.0203 \\
{[0.276]}\end{array}$ & $\begin{array}{l}-0.0018 \\
{[0.572]}\end{array}$ & $\begin{array}{l}-0.0104 \\
{[0.269]}\end{array}$ & $\begin{array}{c}0.0010 \\
{[0.942]}\end{array}$ & $\begin{array}{c}0.1489 * * * \\
{[0.000]}\end{array}$ \\
\hline $\begin{array}{l}\text { Observations } \\
\text { R-squared }\end{array}$ & $\begin{array}{c}8041 \\
0.004\end{array}$ & $\begin{array}{c}747 \\
0.014\end{array}$ & $\begin{array}{c}183 \\
0.080\end{array}$ & $\begin{array}{l}1705 \\
0.009\end{array}$ & $\begin{array}{l}2648 \\
0.006\end{array}$ & $\begin{array}{c}378 \\
0.022\end{array}$ \\
\hline
\end{tabular}




\section{Table VII \\ Frequency Regressions}

This table presents the coefficients and p-values for OLS regression models where the dependent variable is the frequency of acquisitions relative to the number of listed firms in a country (based on the number of firms with return data on Datastream). Variable definitions are in the Appendix. Model (1) is for the unrestricted sample from SDC including cases with missing deal values and private acquirers. Models (2) through (7) use the sample of deals by public acquirers for which deal value is available. Each regression includes calendar year indicator variables (not reported). $\mathrm{N}$ is the number of observations based on country-year observations. Statistical significance of the regression coefficients is denoted with ***, **, or * for $p$-values less than one percent, five percent, and ten-percent respectively.

\begin{tabular}{|c|c|c|c|c|c|c|c|}
\hline VARIABLES & $\begin{array}{c}\text { All } \\
\text { Unrestricted } \\
\text { Sample } \\
(1) \\
\end{array}$ & $\begin{array}{l}\text { All } \\
(2)\end{array}$ & $\begin{array}{c}\text { Public } \\
\text { Targets \& } \\
\text { Cash } \\
(3) \\
\end{array}$ & $\begin{array}{c}\text { Public } \\
\text { Targets \& } \\
\text { Stock } \\
(4) \\
\end{array}$ & $\begin{array}{c}\text { Subsidiary } \\
\text { Targets \& } \\
\text { Cash } \\
\text { (5) } \\
\end{array}$ & $\begin{array}{c}\text { Private } \\
\text { Targets \& } \\
\text { Cash } \\
(6) \\
\end{array}$ & $\begin{array}{c}\text { Private } \\
\text { Targets \& } \\
\text { Stock } \\
(7) \\
\end{array}$ \\
\hline WDI_GOV_AVG & $\begin{array}{c}0.1138^{* * *} \\
{[0.005]}\end{array}$ & $\begin{array}{l}0.0122 * \\
{[0.100]}\end{array}$ & $\begin{array}{c}0.0015^{* * *} \\
{[0.000]}\end{array}$ & $\begin{array}{c}0.0004^{* * *} \\
{[0.009]}\end{array}$ & $\begin{array}{c}0.0037 * * * \\
{[0.000]}\end{array}$ & $\begin{array}{c}0.0041^{* * *} \\
{[0.000]}\end{array}$ & $\begin{array}{c}0.0007^{* * *} \\
{[0.000]}\end{array}$ \\
\hline GDP_PCAP & $\begin{array}{l}-0.0009 \\
{[0.690]}\end{array}$ & $\begin{array}{c}0.0001 \\
{[0.741]}\end{array}$ & & & & & \\
\hline LIB_INT_AVG & $\begin{array}{l}-0.0150 \\
{[0.632]}\end{array}$ & $\begin{array}{c}0.0015 \\
{[0.836]}\end{array}$ & $\begin{array}{l}0.0005 \\
{[0.504]}\end{array}$ & $\begin{array}{l}-0.0006 \\
{[0.501]}\end{array}$ & $\begin{array}{l}-0.0012 \\
{[0.509]}\end{array}$ & $\begin{array}{l}0.0018 \\
{[0.490]}\end{array}$ & $\begin{array}{l}-0.0005 \\
{[0.366]}\end{array}$ \\
\hline SECLAW & $\begin{array}{l}-0.0367 \\
{[0.376]}\end{array}$ & $\begin{array}{l}-0.0022 \\
{[0.833]}\end{array}$ & $\begin{array}{l}-0.0003 \\
{[0.702]}\end{array}$ & $\begin{array}{l}-0.0002 \\
{[0.636]}\end{array}$ & $\begin{array}{l}-0.0005 \\
{[0.787]}\end{array}$ & $\begin{array}{l}-0.0008 \\
{[0.809]}\end{array}$ & $\begin{array}{c}0.0005 \\
{[0.226]}\end{array}$ \\
\hline ANTI_SD & $\begin{array}{l}-0.1114 \\
{[0.281]}\end{array}$ & $\begin{array}{c}0.0155 \\
{[0.544]}\end{array}$ & $\begin{array}{c}-0.0031^{*} \\
{[0.075]}\end{array}$ & $\begin{array}{c}0.0004 \\
{[0.601]}\end{array}$ & $\begin{array}{l}-0.0003 \\
{[0.951]}\end{array}$ & $\begin{array}{c}0.0054 \\
{[0.458]}\end{array}$ & $\begin{array}{c}0.0003 \\
{[0.654]}\end{array}$ \\
\hline MKTCAP_GDP & $\begin{array}{l}0.0179 \\
{[0.355]}\end{array}$ & $\begin{array}{l}-0.0003 \\
{[0.954]}\end{array}$ & $\begin{array}{c}0.0010^{* * *} \\
{[0.007]}\end{array}$ & $\begin{array}{c}0.0001 \\
{[0.668]}\end{array}$ & $\begin{array}{c}0.0001 \\
{[0.886]}\end{array}$ & $\begin{array}{l}-0.0002 \\
{[0.899]}\end{array}$ & $\begin{array}{l}0.0000 \\
{[0.925]}\end{array}$ \\
\hline CTRY_RET_1YR & $\begin{array}{l}0.0096 \\
{[0.498]}\end{array}$ & $\begin{array}{c}0.0024 \\
{[0.410]}\end{array}$ & $\begin{array}{c}0.0008 \\
{[0.311]}\end{array}$ & $\begin{array}{l}-0.0001 \\
{[0.725]}\end{array}$ & $\begin{array}{c}0.0004 \\
{[0.594]}\end{array}$ & $\begin{array}{l}-0.0002 \\
{[0.904]}\end{array}$ & $\begin{array}{c}0.0004 \\
{[0.621]}\end{array}$ \\
\hline $\begin{array}{l}\text { N } \\
\text { Adiusted R-sauared }\end{array}$ & $\begin{array}{l}502 \\
0.43\end{array}$ & $\begin{array}{c}502 \\
0217\end{array}$ & $\begin{array}{c}502 \\
0.191\end{array}$ & $\begin{array}{c}502 \\
0.068\end{array}$ & $\begin{array}{c}502 \\
0.163\end{array}$ & $\begin{array}{c}502 \\
0145\end{array}$ & $\begin{array}{c}502 \\
0131\end{array}$ \\
\hline
\end{tabular}

